\title{
Lusioersily
}

\section{Immunological axis of berberine in managing inflammation underlying chronic respiratory inflammatory diseases}

Tew, X. N., Xin Lau, N. J., Chellappan, D. K., Madheswaran, T., Zeeshan, F., Tambuwala, M. M., Aljabali, A. A., Balusamy, S. R., Perumalsamy, H., Gupta, G., Oliver, B. G., Hus, A., Wark, P., Reddy, K., Wadhwa, R., Hansbro, P. M., \& Dua, K. (2020). Immunological axis of berberine in managing inflammation underlying chronic respiratory inflammatory diseases. Chemico-Biological Interactions, 317, [108947]. https://doi.org/10.1016/j.cbi.2020.108947

Link to publication record in Ulster University Research Portal

\section{Published in:}

Chemico-Biological Interactions

\section{Publication Status:}

Published (in print/issue): 01/02/2020

DOI:

10.1016/j.cbi.2020.108947

\section{Document Version}

Author Accepted version

\section{General rights}

Copyright for the publications made accessible via Ulster University's Research Portal is retained by the author(s) and / or other copyright owners and it is a condition of accessing these publications that users recognise and abide by the legal requirements associated with these rights.

\section{Take down policy}

The Research Portal is Ulster University's institutional repository that provides access to Ulster's research outputs. Every effort has been made to ensure that content in the Research Portal does not infringe any person's rights, or applicable UK laws. If you discover content in the Research Portal that you believe breaches copyright or violates any law, please contact pure-support@ulster.ac.uk. 


\title{
Manuscript Details
}

\section{Manuscript number}

Title
CHEMBIOINT_2019_1718_R2

Immunological axis of Berberine in Managing Inflammation Underlying Chronic Respiratory Inflammatory Diseases

Review Article

\section{Article type}

\begin{abstract}
Inflammatory responses play a remarkable role in the mechanisms of acute and chronic respiratory diseases such as chronic obstructive pulmonary disease (COPD), asthma, pulmonary fibrosis and lung cancer. Currently, there is a resurgence in the use of drugs from natural sources for various ailments as potent therapeutics. Berberine, an alkaloid prominent in the Chinese traditional system of medicine has been reported to exert therapeutic properties in various diseases. Nevertheless, the number of studies focusing on the curative potential of berberine in inflammatory diseases involving the respiratory system is limited. In this review, we have attempted to discuss the reported anti-inflammatory properties of berberine that function through several pathways such as, the NF- $\square$ B, ERK1/2 and p38 MAPK pathways which affect several pro-inflammatory cytokines in the pathophysiological processes involved in chronic respiratory diseases. This review would serve to provide valuable information to researchers who work in this field and a new direction in the field of drug discovery with respect to respiratory diseases.
\end{abstract}

\section{Keywords}

Taxonomy

Manuscript category

Corresponding Author

Corresponding Author's Institution

Order of Authors

Suggested reviewers
Berberine; inflammatory diseases; respiratory diseases; COPD; asthma; pulmonary fibrosis

Toxicology, Pharmaceutical Science

Biochemical toxicology

Kamal Dua

University of Sydney Technology

Xin Nee Tew, Natalie Jia Xin Lau, Dinesh Kumar Chellappan, Thiagarajan Madheswaran, Farrukh Zeeshan, Murtaza Tambuwala, Alaa AA. Aljabali, Sri Renukadevi Balusamy, Haribalan Perumalsamy, gaurav gupta, Brian G. Oliver, Alan Hsu, Peter Wark, Karosham Reddy, Ridhima Wadhwa, Philip Michael Hansbro, Kamal Dua

Janet Wong, Joseph Bloom, David Finlay

\section{Submission Files Included in this PDF}

\section{File Name [File Type]}

Cover Letter (3).docx [Cover Letter]

Response to reviewer comments (3).docx [Response to Reviewers]

Revised Berberine Review (2).docx [Revised Manuscript with Changes Marked]

Highlights.docx [Highlights]

Revised Manuscript.docx [Manuscript File]

Revised Figures.docx [Figure]

Revised Tables.docx [Table]

declaration-of-competing-interests.docx [Conflict of Interest]

To view all the submission files, including those not included in the PDF, click on the manuscript title on your EVISE Homepage, then click 'Download zip file'. 
Dr Kamal Dua,

University of Technology Sydney

Editor-in-Chief

Chemico Biological Interactions

Subject: Submission of the revised review for publication in the journal Chemico Biological Interactions

Dear Editor,

Please find attached our revised review entitled "Immunological axis of Berberine in Managing Inflammation Underlying Chronic Respiratory Inflammatory Diseases" for your kind consideration for publication in the journal, Chemico Biological Interactions. The present review is original and has not been published elsewhere, nor is it currently under consideration for publication elsewhere.

Inflammatory response plays a remarkable role in the mechanisms of acute and chronic respiratory diseases such as chronic obstructive pulmonary disease (COPD), asthma, pulmonary fibrosis and lung cancer. Herbal medicine has been widely used in therapeutics. Berberine, an alkaloid prominent in Chinese medicine, Rhizoma Coptis, has been shown to exert therapeutic properties in various diseases. Nevertheless, the number of researches focusing on the curative potential of Berberine in inflammatory diseases involving the respiratory system is limited. In this review, we focused on the anti-inflammatory properties of Berberine functioning through several pathways such as the NF-KB, ERK1/2 and p38 MAPK pathways, impacting several pro-inflammatory cytokines. We also discuss its role in the treatment of respiratory diseases, providing a new direction in the field of drug discovery with respect to respiratory diseases.

Our study, emphasizing the importance of berberine in combating respiratory inflammatory diseases, would be of great interest to pharmaceutical scientists, pharmacist and clinicians. Our study can form the basis for further detailed research in this field, which can help in targeting a better treatment option for respiratory inflammatory diseases. We hope that you find our review acceptable for publication in the journal, Chemico Biological Interactions.

Kindest regards,

Dr Kamal Dua

Disclosures:

All the authors have participated and have contributed in the preparation of the manuscript. In addition, all authors have also approved the final version of the drafted manuscript. 


\section{RESPONSE TO REVIEWER COMMENTS}

Manuscript-ID: CHEMBIOINT_2019_1718 [Journal-Chemico-Biological Interactions]

Manuscript title: Immunological axis of Berberine in Managing Inflammation Underlying Chronic Respiratory Inflammatory Diseases

Author list: Xin Nee Tew, Natalie Jia Xin Lau, Dinesh Kumar Chellappan, Thiagarajan Madheswaran, Farrukh Zeeshan, Murtaza M. Tambuwala, Alaa AA. Aljabali, Sri Renukadevi Balusamy, Haribalan Perumalsamy, Gaurav Gupta, Brian G. Oliver, Philip Michael Hansbro, Alan Hsu, Peter Wark, Karosham Reddy, Ridhima Wadhwa, Kamal Dua

Note: All changes have been made in red in the main manuscript

\begin{tabular}{|l|l|l|}
\hline 1. & \multicolumn{1}{|c|}{ Comments by Editors/Reviewers } & \multicolumn{1}{|c|}{$\begin{array}{c}\text { Response from the } \\
\text { authors }\end{array}$} \\
\hline 1. & $\begin{array}{l}\text { This review is potentially interesting and relevant. My major } \\
\text { comments regard the lack of quantitative data. Not a single barberine } \\
\text { dose/concentration is mentioned in the manuscript. Were doses of } \\
\text { barberine identified in the studies cited in the manuscript? Was the } \\
\text { barberine dose-response relationship defined? There is no information } \\
\text { on the pharmacokinetics of barberine. Has this been studied? In the } \\
\text { conclusions, it is mentioned that "Preliminary clinical trials have } \\
\text { proven the anti-inflammatory effect of berberine", but there is no } \\
\text { mention of these studies in the manuscript. These limitations, which } \\
\text { are not mentioned in the manuscript, preclude the assessment of the } \\
\text { potential clinical utility of barberine. I would suggest to include this } \\
\text { information in the revised manuscript if available. If not, these points } \\
\text { should be carefully presented and discusses and limitations should be } \\
\text { emphasized. }\end{array}$ & $\begin{array}{l}\text { Thank you for } \\
\text { comments and } \\
\text { observations. We have } \\
\text { now included, in the } \\
\text { manuscript, the doses } \\
\text { and concentrations of } \\
\text { Berberine that were } \\
\text { identified from the } \\
\text { mentioned studies, } \\
\text { whichever available. A } \\
\text { brief information on the } \\
\text { pharmacokinetics and the } \\
\text { limitations of Berberine } \\
\text { are also included. }\end{array}$ \\
\hline
\end{tabular}




\section{Immunological axis of Berberine in Managing Inflammation Underlying Chronic Respiratory Inflammatory Diseases}

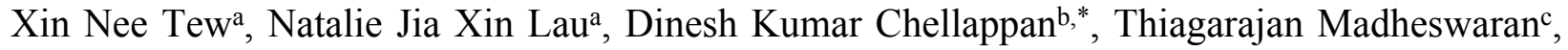
Farrukh Zeeshan $^{\mathrm{c}}$, Murtaza M. Tambuwala ${ }^{\mathrm{d}}$, Alaa AA. Aljabalie, Sri Renukadevi Balusamy ${ }^{\mathrm{f}}$, Haribalan Perumalsamy ${ }^{\mathrm{g}}$, Gaurav Gupta ${ }^{\mathrm{h}}$, Brian G. Oliver ${ }^{\mathrm{i}, \mathrm{j}}$, Alan Hsul, Peter Wark ${ }^{1}$, Karosham Reddy,j, Ridhima Wadhwa ${ }^{\mathrm{k}, \mathrm{l}}$, Philip Michael Hansbro ${ }^{\mathrm{k}, 1, \mathrm{~m}}$, Kamal Dua $^{\mathrm{k}, 1, \mathrm{~m}, \mathrm{n}^{*}}$

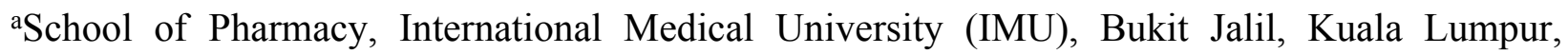
57000, Malaysia

bepartment of Life Sciences, School of Pharmacy, International Medical University (IMU), Bukit Jalil, Kuala Lumpur, 57000, Malaysia

'Department of Pharmaceutical Technology, School of Pharmacy, International Medical University (IMU), Bukit Jalil, Kuala Lumpur, 57000, Malaysia

${ }^{\mathrm{d} S c h o o l ~ o f ~ P h a r m a c y ~ a n d ~ P h a r m a c e u t i c a l ~ S c i e n c e s, ~ U l s t e r ~ U n i v e r s i t y, ~ C o l e r a i n e, ~ C o u n t y, ~}$ Londonderry, BT52 1SA, Northern Ireland, United Kingdom

eFaculty of Pharmacy, Department of Pharmaceutical Sciences, Yarmouk University, Irbid 21163, Jordan

fDepartment of Food Science and Biotechnology, Sejong University, Gwangjin-gu, Seoul 05006, Republic of Korea

gGraduate School of Biotechnology, College of Life Sciences, Kyung Hee University, Yongin 446-701, Republic of Korea 
hSchool of Pharmacy, Suresh Gyan Vihar University, Jagatpura 302017, Mahal Road, Jaipur, India

iSchool of Life Sciences, Faculty of Science, University of Technology Sydney (UTS), Ultimo, NSW, 2007, Australia

${ }^{j}$ Respiratory Cellular and Molecular Biology Group, Woolcock Institute of Medical Research, Sydney, Australia

kDiscipline of Pharmacy, Graduate School of Health, University of Technology Sydney (UTS), Ultimo, NSW, 2007, Australia

'School of Life Sciences, Faculty of Science, University of Technology Sydney (UTS), Ultimo, NSW, 2007, Australia

mPriority Research Centre for Healthy Lungs, Hunter Medical Research Institute (HMRI) \& School of Biomedical Sciences and Pharmacy, The University of Newcastle (UoN), Callaghan, NSW, 2308, Australia

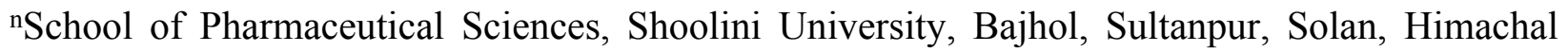
Pradesh, 173 229, India

*Corresponding authors

1. Dr Dinesh Kumar Chellappan

Email address: dineshkumarchellappan.imu@gmail.com

2. Dr Kamal Dua

Email address: kamalpharmacist02@gmail.com 


\begin{abstract}
Inflammatory responses play a remarkable role in the mechanisms of acute and chronic respiratory diseases such as chronic obstructive pulmonary disease (COPD), asthma, pulmonary fibrosis and lung cancer. Currently, there is a resurgence in the use of drugs from natural sources for various ailments as potent therapeutics. Berberine, an alkaloid prominent in the Chinese traditional system of medicine has been reported to exert therapeutic properties in various diseases. Nevertheless, the number of studies focusing on the curative potential of berberine in inflammatory diseases involving the respiratory system is limited. In this review, we have attempted to discuss the reported anti-inflammatory properties of berberine that function through several pathways such as, the NF-кB, ERK1/2 and p38 MAPK pathways which affect several pro-inflammatory cytokines in the pathophysiological processes involved in chronic respiratory diseases. This review would serve to provide valuable information to researchers who work in this field and a new direction in the field of drug discovery with respect to respiratory diseases.
\end{abstract}

Keywords: Berberine; inflammatory diseases; respiratory diseases; COPD; asthma; pulmonary fibrosis; lung cancer.

\title{
1. Introduction
}

Inflammation is a defense response of the human body against injury or infectious agents with the primary intent to remove noxious stimuli and to promote healing. ${ }^{1,2}$ Signs and symptoms such as rubor, calor, tumor, dolor, and functio laesa, which are also known as redness, heat, swelling, pain and loss of function respectively are associated with the cellular and molecular events that occur during an inflammatory response. ${ }^{2}$ Ideally, acute inflammation resolves when the body homeostasis has been restored, after the injury or the invaded stimuli..$^{1,3}$ 
However, uncontrolled and untreated inflammation can progress into various inflammatory diseases.

Inflammatory diseases that involve the respiratory system may impair gas exchange, resulting in hypoxia and eventually leading to death. The lungs are being constantly exposed to pathogens, allergens, irritants or toxic molecules in the atmosphere and thus, the pulmonary defense system is vital in protecting the integrity and function of the respiratory system. The balance between the inflammatory responses and the anti-inflammatory mechanism, therefore, are important in regulating lung homeostasis. ${ }^{4}$ Acute respiratory inflammation involves neutrophils while, chronic lung inflammation involves lymphocytes and macrophages. In acute pulmonary inflammation, chemotactic factors are expressed by activated endothelial cells, resulting in a chemotactic gradient that first causes the migration of neutrophils and then the production of chemokines. ${ }^{4}$ Acute respiratory distress syndrome (ARDS) and pneumonia are notable examples that results from acute pulmonary inflammation. ${ }^{5-7}$ Chronic respiratory inflammation, on the other hand, involves lymphocytes and macrophages and is the direct result of incomplete recovery from acute lung inflammation and its responses. In addition, chronic inflammation also includes the presence of necrotic debris and apoptotic cells which are the resultant products of the acute injury. ${ }^{4}$ Chronic lung inflammation is often associated with chronic obstructive pulmonary disease (COPD), asthma, lung cancer and pulmonary fibrosis. ${ }^{5-7}$

Plants have been widely used for medical purposes for thousands of years. Plants are known to relieve symptoms of various ailments. ${ }^{74}$ In several traditional systems of medicine namely, Ayurveda, Traditional Chinese Medicine (TCM) and Egyptian medicine, plants including herbs, are utilised for their medicinal properties for treating illnesses, improving health and disease prevention. ${ }^{74}$ Herbal medicines in different forms target specific parts of the human 
body.$^{75}$ For instance, raw garlic aids in the respiratory system, treating asthma, whereas, mashed vinegar-macerated garlic relieves toothaches and sore throats. ${ }^{75}$ In the current era, herbal medicines have been massively replaced by modern drugs. Nonetheless, the use of herbal medicines is highly exercised throughout the world.

Berberine is a benzylisoquinoline alkaloid (Figure 1) that can be normally found in the barks, stems, rhizomes or roots of various plant sources, including Arcangelisia flava (Yellow Fruit Moonseed), Berberis aquifolium (Oregon grape), Rhizoma coptidis ('Huang Lian'), Berberis vulgaris (Barberry), Coptis chinensis (Coptis or Goldenthread), Berberis aristata (Tree Turmeric), Hydrastis Canadensis (Goldenseal), Phellodendron chinense (Chinese Cork Tree) and Phellodendron amurense (Amur cork tree). ${ }^{76-82}$ The first recorded use of berberine (Rhizoma coptidis) as folk medicine can be traced back to A.D. 200 in China, used by the father of Chinese medicine, Shennong. ${ }^{81-83}$ Rhizoma coptidis was traditionally used to treat the complications associated with diabetes for over 1500 years. Berberine containing plants were also widely used in ancient Ayurvedic medicine due to its anti-protozoal and anti-microbial activities. ${ }^{80}$ Among the various sources of berberine, Berberis aristata was widely mentioned in the scriptures of Ayurveda, Sushruta and Charaka. ${ }^{84}$ Berberis aristata was also used in homeopathy to treat diseases back in time. Some of the most common marketed formulations containing berberine that are sold in the US are listed in Table 2. Berberine, when subjected to pharmacokinetic studies, using rat plasma revealed the presence of four major metabolites, namely, berberrubine, thalifendine, demethyleneberberine, and jatrorrhizine, as free and glucuronide conjugates.

\subsection{Chronic obstructive pulmonary disease (COPD)}

Chronic obstructive pulmonary disease (COPD) primarily corresponds to severe and prolonged inflammation of the airways. Tobacco smoke is recognised as one of the primary 
causes of COPD, nevertheless, air pollution, chemical fumes, poisonous gases, particlates and dust are also associated with disease onset. ${ }^{8-10}$ Based on the Global Burden Disease Study 2017, COPD is one of the seven diseases that contributes to more than one million deaths each around the world. ${ }^{11}$ People with COPD either experience chronic bronchiolitis, emphysema or a combination of both. Chronic bronchiolitis involves severe inflammation and swelling of the airways, eventually leading to a decreased size of the airways. Emphysema, on the other hand, is specifically characterized as the loss of elasticity of the alveoli wall which prevents the emptying of air and therefore, results in breathing difficulty. This condition, eventually over a period of time, culminates in shortness of breath (dyspnea). ${ }^{8-10,12}$ In COPD, there is an elevation in the levels of neutrophils and macrophages. Barnes et al., reported that activated macrophages release high levels of inflammatory mediators such as IL-6, IL-1 $\beta$ and TNF- $\alpha .{ }^{9}$ Exposures to cigarette smoke (CS) and lipopolysaccharides (LPS) remarkably elevate inflammatory cell counts, specifically the neutrophil counts. Furthermore, CS and LPS exposures increase the levels of pro-inflammatory cytokines namely, TNF- $\alpha$, IL-1 $\beta$ and IL-6. Exposure to LPS along with elevated TNF- $\alpha$ level increase phosphorylation of the transcription factor, nuclear factor- $\mathrm{\kappa B}$ (NF-kB), causing the degradation of I $\mathrm{B} \alpha$. This then causes production of induced nitric oxide synthase (iNOS) and matrix metalloproteinases (MMPs). ${ }^{13,14}$ Expression of iNOS induced by cytokines further causes the production of nitric oxide, promoting inflammatory response of pulmonary cells. ${ }^{15,16}$ Furthermore, MMPs are endopeptidases that destroy the matrix proteins, leading to the destruction of the normal structure of alveoli, exacerbating pulmonary inflammation and eventually inducing emphysema. All these factors contribute to a loss in the lung function. ${ }^{13,17}$ Based on the American College of Physicians Clinical Practice guidelines, the first-line management of COPD is monotherapy with either long-acting $\beta$-agonist (LABA) or 
inhaled anticholinergic. ${ }^{18,19}$ However, treatment with LABA has been reported to induce several adverse effects including tremor, palpitation, arrythmias and cardiac ischaemia. ${ }^{20}$

\subsection{Asthma}

Asthma is the result of reversible airway obstruction, resulting from airway inflammation and hyperresponsiveness. ${ }^{21}$ The clinical symptoms of asthma involve shortness of breath, wheezing, chest tightness and sometimes cough, where death can occur if the symptoms do not relieve on time. ${ }^{22}$ According to a systematic analysis by Abajobir et al., in 2015, asthma has the highest prevalence compared to other chronic respiratory diseases throughout the world. ${ }^{23}$ However, the death rate of asthma had decreased $26.7 \%$ as compared from the year 1990, with $1 \%$ of global disability-adjusted life years (DALYs) from the earlier $2.6 \%$ of global DALYs. ${ }^{23}$ Asthma is a hyper-responsive allergic reaction in the airways that is normally acquired in all ages. Atopic asthma is commonly acquired in the childhood, where the airway inflammation involves over-reaction of specific immunoglobulin E (IgE) antibodies. ${ }^{24}$

Although asthma is still incurable, inhaled corticosteroids (ICS) are the first line management for patient with persistent asthma. ${ }^{25}$ This is because ICS are effective in controlling asthma exacerbation even at a low dose. ${ }^{25}$ However, ICS work only by suppressing the inflammatory reactions in the airway, without providing a perfect solution for asthma cure. ${ }^{25}$ Other than that, high dose use of ICS in patients with severe asthma might be associated with local and systemic side effect such as oral candidiasis, bruising and cataracts. ${ }^{25}$

In asthmatic patients, the defective airway epithelial barrier allows the stimulus to pass through the airway tissues ${ }^{26}$ which triggers an immune response, leading to narrowing of the airway and hypersecretion of airway mucus. ${ }^{26} \mathrm{NF}-\mathrm{\kappa B}$ and caspase-1 signalling pathways play an 
essential role in the pathophysiology of asthma. ${ }^{27-31}$ Both pathways involve in thymic stromal lymphopoietin (TSLP) production, which is highly related to the pathogenesis of atopic asthma and other allergic diseases. ${ }^{27,28,32-37}$ TSLP is a pro-allergic cytokine that acts on a variety of cells during inflammatory events, including eosinophils, basophils, dendritic cells, mast cells, B cells, innate type II cells, CD4(+) T cells, CD8(+) T cells, natural killer T cells, as well as, epithelial cells. $^{38-40}$ Other than regulating the production of TSLP, NF- $\kappa$ B signalling pathway also regulates the production of inflammatory cytokines and immunoglobulins in asthma. ${ }^{29-31}$ Activation of NF- $\mathrm{BB}$ signaling pathways can increase the production of inflammatory cytokines such as IL-1 $\beta$, IL-2, IL-4, IL-5, IL-6, IL-13, and IL-17.41 Increased production of IL-2, IL-5 and IL-13 from T-helper (Th)2 cells will subsequently increase the production of B-lymphocyte $\operatorname{IgE}$, leading to asthmatic reactions. ${ }^{41,42}$ Moreover, prolonged eosinophil inflammation during asthma

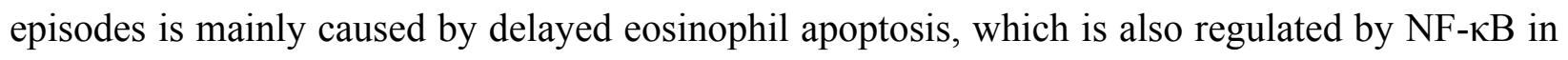
the body. ${ }^{43-45}$ In other words, NF- $\kappa$ B pathway also plays a vital role in the infiltration and function of the inflammatory cells. To conclude with all the existing findings, the suppression of NF- $\kappa \mathrm{B}$ and caspase-1 signalling pathways might be an alternative approach in the therapeutic intervention of asthma medication.

\subsection{Pulmonary fibrosis}

Pulmonary fibrosis is a chronic pulmonary disease which is often caused by dysregulated healing of a lung injury. ${ }^{46,47}$ Pulmonary fibrosis is characterized by worsening lung functions along with respiratory failure. This condition is associated with high mortality and economic burden. ${ }^{46-48}$ Idiopathic pulmonary fibrosis (IPF), which is caused by unknown factors, is the

most common type of pulmonary fibrosis diagnosed worldwide. ${ }^{46-48}$ Although, there are no comprehensive systematic reviews on IPF to date, the incidences of IPF in North America and 
Europe were in the range of 3-9 per 100,000 cases each year, according to the data compiled by Hutchinson et al. ${ }^{49}$ Pulmonary fibrosis is considered as a rare disease, but the incidence rates and severity have increased over the years. ${ }^{50}$ In normal conditions, the lungs when injured by noxious agents will go through different phases of wound healing, namely, injury, inflammation, and repair. Following the wound-healing processes, the damage of the injured organ will be minimized, and the architecture of the lung tissue will be restored to reacquire normal function. ${ }^{46,47}$ However, repetitive stimulation and injury of the lung tissue with noxious agents such as toxic chemical, allergens, radiation or other unknown factors may result in the dysregulation of the tissue repair responses, triggering a persistent inflammatory response. ${ }^{46-48}$ The extensive and recurring inflammation will then progressively evolve into pathogenic fibrotic response, causing fibrosis in the lungs and eventually impair the exchange of gases in the system. $^{46-48}$

Pulmonary fibrosis is normally associated with significant histological changes in lung architecture, mostly caused by extensive mesenchymal cell proliferation, that eventually lead to excessive collagen deposition. ${ }^{51}$ High levels of hydroxyproline often reflects the accumulation of collagen in the lung tissues. ${ }^{52,53}$ In addition to that, mast cell proliferation also contributes a essential role in the pathogenesis of pulmonary fibrosis. During the inflammatory response, degranulated mast cells release histamine, which increases the secretion of fibrogenic cytokines via the upregulation of fibroblast activation..$^{54,55}$

Similar to other chronic respiratory diseases, NF- $\mathrm{kB}$ signalling pathway is also involved in the pathophysiology of pulmonary fibrosis. Activation of NF-kB pathway is associated with elevation in the levels of nitric oxide synthase (iNOS), TGF- $\beta 1$, and TNF- $\alpha .{ }^{54}$ Enhanced activation of iNOS increases the production of nitric oxide (NO) in the body, resulting in severe 
oxidative stress. Free radical peroxidation products produced under increased oxidative stress, causes the destruction of cell membrane and eventually leads to pulmonary fibrosis. ${ }^{56,57}$ On the other hand, increased levels of multi-function cytokines, namely, TGF- $\beta 1$ are highly associated to the pathogenesis of pulmonary fibrosis, as they stimulate the growth of myofibroblasts and fibroblasts, promoting the synthesis and deposition of extracellular matrix (ECM) and suppress the degradation of collagen while promoting its deposition and synthesis in the lung tissue. ${ }^{54,58,59}$

Moreover, pulmonary fibrosis is also associated with oxidative tissue damage, which is often indicated by increased activity of malondialdehyde (MDA), hydroperoxides (OH) and nitrite (NO). ${ }^{54,60,61}$ The redox sensing transcription factor, nuclear factor E2-related factor 2 (Nrf2) also plays a vital role in maintaining the balance between the activity of oxidants and antioxidants in the cells. ${ }^{54}$ Dysregulated Nrf2 is often one of the factors that is associated with aggravating pulmonary fibrosis. In addition, inflammatory cell infiltration often contributes an essential role in the pathophysiology of pulmonary fibrosis, and the level of myeloperoxidase (MPO) can be used to indicate the degree of neutrophilic accumulation in the body tissue. ${ }^{62}$

To date, the only cure available for IPF is lung transplantation and the most recent first line antifibrotic agents approved by the FDA (pirfenidone and nintedanib) can only stabilize and delay the disease progression in IPF, without providing absolute cure from the disease. ${ }^{48,63}$ Therefore, further efforts are needed to discover advanced and potent pharmacotherapy for pulmonary fibrosis.

\subsection{Lung Cancer}

Lung cancer is another respiratory disease that involves the inflammatory response and has the highest mortality rate worldwide. ${ }^{64}$ Based on the Global Cancer Statistics 2018, lung 
cancer has the highest incidence rate, contributing to $11.6 \%$ of all cancer diagnosis. Lung cancer, being the leading cause of cancer deaths, comprises of $18.4 \%$ of cancer deaths in total with an estimation of over 1.8 million deaths over a year. ${ }^{64}$ Lung cancer can be categorised into two major types; non-small cell lung cancer (NSCLC) and small cell lung cancer (SCLC). The diagnosis rate of NSCLC (85\%) is comparably higher than SCLC (15\%), with a ratio of approximately 5:1. ${ }^{65,66} \mathrm{SCLC}$ first appears in the bronchi, which is located in the center of the chest. NSCLC on the other hand, can be further categorized into three sub-classifications, namely adenocarcinoma (40\%), squamous-cell carcinoma (30\%) and large-cell lung cancer (10\%). In particular, squamous-cell carcinoma is most closely linked with cigarette smoking. ${ }^{65}$ According to Hanahan et al., the main indications of cancer, in general, include uncontrollable cell proliferation, eluding of growth factors, angiogenesis, invasions of hyper-proliferating cells and metastasis. ${ }^{67}$ Inflammatory molecules play a crucial role in the development of lung cancer involving several events that may affect the malignancy of tumours. Gomes et al., reported that inflammatory cells function as tumour promoters that are responsible in the formation of malignant tumours from initiated cells. The dysregulation of cell growth results in the production of inflammatory molecules, including chemokines and cytokines that facilitate the development of cancer. TNF- $\alpha, \mathrm{NF}-\mathrm{\kappa B}$ and TGF- $\beta$ are a few of the cytokines that contribute towards the development of cancer. ${ }^{66} \mathrm{P} 38$ mitogen activated protein kinase (p38/MAPK), particularly p38 has been reported to suppress cell proliferation. Nonetheless, in lung cancer, the activated p38 is downregulated, and hence, initiates cell growth. ${ }^{68}$ Moreover, signal transducer and activator of transcription 3 (STAT3) is a transcription factor that plays a significant role in the pathogenesis of lung cancer. The activation of STAT3 not only promotes cell proliferation, but also initiates survival of tumour cells. ${ }^{69}$ The treatment of SCLC is divided in to two stages, namely limited 
stage (LS) and extensive stage (ES). In the study conducted by Kalemkerian et al., the standard treatment of LS-SCLC is chemotherapy with carboplatin or cisplatin, with the addition of etoposide for approximately 4 to 6 cycles, together with early, concurrent thoracic radiotherapy (RT). As for patients with stage 1 LS-SCLC, the treatment option is surgical excision followed by adjuvant chemotherapy. Patients with ES-SCLC on the other hand, can be treated with platinum-based chemotherapy of two drugs such as cisplatin and etoposide for 4 to 6 cycles, followed by prophylactic cranial irradiation (PCI) if patients respond well to initial chemotherapy. ${ }^{70-72}$ Furthermore, stage I, II and IIIA NSCLC patients can be treated with surgical resection, whereas, patients with stage IIA, IIB and IIIA NSCLC normally receive chemotherapy following surgery to ensure all remaining cancer cells are killed. Nonetheless, radiotherapy is the alternative treatment for patients who are not suitable for surgery and do not respond to chemotherapy. ${ }^{73}$

\section{The role of berberine in respiratory inflammatory diseases}

\subsection{Berberine and COPD}

HwangRyunHaeDok-Tang (HRHD), an Eastern herbal formula, used not only in China, but also in Korea and Japan to treat inflammatory diseases, contains 4 major constituents. ${ }^{85}$ One of the main components of HRHD is Coptidis rhizoma, which contains the anti-inflammatory substance, berberine. ${ }^{13,85}$ A study conducted by Shin et al., reported a decrease in neutrophil counts in the broncho-alveolar lavage fluid (BALF) in HRHD treated animals. The rats were administered with either $100 \mathrm{mg} / \mathrm{kg}$ or $200 \mathrm{mg} / \mathrm{kg}$ of the formulation. Moreover, HRHD-treated organisms are found to have reduced levels of TNF- $\alpha$, IL-1B and IL-6. HRHD is also found to inhibit NF- $\kappa \mathrm{B}$ activation, eventually decreasing its activity, which then results in the suppression

of inflammatory responses caused by both CS and LPS exposures. The increased expression and 
activity of MMPs are also suppressed in HRHD-administered animals. ${ }^{13}$ Another study conducted by Lin et al., reported that berberine, at a dose of $50 \mathrm{mg} / \mathrm{kg}$, when administered intragastrically, significantly caused a decline in the number of neutrophils and total cells in BALF. Myeloperoxidase (MPO) activity that indicates the neutrophil accumulation in the lungs, caused by CS exposure, is also reduced in berberine-administered mice. Decrease in proinflammatory cytokine (TNF- $\alpha$ and IL-6) levels is also noticed in berberine-treated mice. Besides, berberine also causes a crucial decrease in NF- $\mathrm{kB}$ nuclear translocation and its DNA activity. ${ }^{86} \mathrm{Li}$ et al., reported that berberine pre-treatment at $1.25 \mu \mathrm{M}$ concentration decreases the mRNA expression of iNOS. Cell lines treated with berberine demonstrated a suppressive effect on the levels of pro-inflammatory cytokines (TNF- $\alpha$, IL-1 $\beta$ and IL-6). In in vivo studies, berberine at a dose of $20 \mathrm{mg} / \mathrm{kg}$ demonstrated a significant reduction in inflammation in mice.

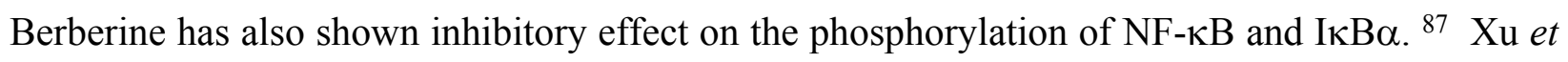
al., also reported in their study that berberine reduces the accumulation of total cells in BALF, at the same time, suppresses the entry of neutrophils into BALF. Levels of inflammatory mediators (TNF- $\alpha$, IL-1 $\beta$ and MCP-1) were found to be remarkably reduced in berberine-treated mice at doses of either $5 \mathrm{mg} / \mathrm{kg}$ or $10 \mathrm{mg} / \mathrm{kg}$. In addition, p38MAPK activity that portrays an important role in COPD is found to be attenuated in mice administered with berberine. ${ }^{88}$ Hence, the antiinflammatory properties of berberine presents a potential case in the treatment of COPD.

\subsection{Berberine and asthma}

High levels of TSLP expressions have been detected in asthmatic airways in human and animal models, and researchers suggest that suppression of TSLP will be a positive approach to modulate allergic inflammatory diseases including asthma. ${ }^{32-37}$ Berberine has shown to suppress TSLP expression effectively. Based on the studies carried out by Moon et al., (2011), decreased 
TSLP production and mRNA expression were observed in HMC-1 cells in berberine treatment group of different concentrations without showing cytotoxicity. ${ }^{36}$ The TSLP production was also reduced in primary mast cells under the treatment of berberine. The researchers concluded that the low TSLP production is highly associated to the downregulation of NF- $\mathrm{kB}$ and caspase-1 pathway in HMC-1 cells by berberine..$^{27,28}$ These results proved that TSLP production is governed by NF- $\mathrm{KB}$ and caspase-1 pathways, and inhibition of both these pathways can result in low TSLP production. ${ }^{27,28}$ The study also suggested that berberine can modulate the inflammatory response associated with PMA plus A23187 via inhibiting the production of TSLP, and berberine can be one of the potential therapeutic interventions in treating asthma.

In addition to regulating the production of TSLP, berberine also has been shown to inhibit NF-kB signalling pathway and its subsequent inflammatory response effectively. Li et al., studied the anti-inflammatory effects of berberine on ovalbumin-induced asthma in experimental rats. ${ }^{41}$ The rats were administered either $100 \mathrm{mg} / \mathrm{kg}$ or $200 \mathrm{mg} / \mathrm{kg}$ of berberine. Based on the results, the signalling of NF-kB pathway was inhibited by berberine treatment. When compared to berberine treatment group, vehicle group and control group, similar expression of IкB $\alpha$

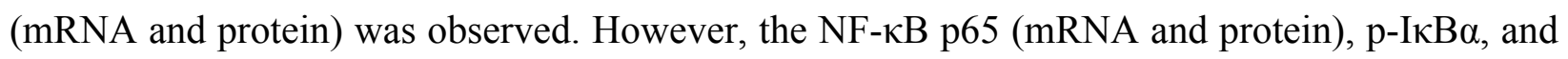
p-NF-kB p65 expression were found to be markedly lower in berberine treated group. The groups treated with berberine also showed lower NF- $\mathrm{kB}$ p65 DNA binding activity compared to the vehicle group. It also significantly reduced the levels of inflammatory cytokines (IL-1 $\beta$, IL-4, IL-5, IL-6, IL-13, and IL-17) and OVA-specific IgE in BALF in contrast with the vehicle group in a dose-dependent pattern. It is hypothesized that NF- $\mathrm{kB}$ pathway regulates the production of inflammatory cytokines, and suppression of this pathway by berberine decreases the level of inflammatory cytokines. ${ }^{41}$ Suppression of NF- $\mathrm{kB}$ pathway also indirectly decreases the 
production of B-lymphocyte IgE due to low production of cytokines such as IL-2, IL-5 and IL-13 by Th2 cells. ${ }^{41,42}$ Besides, the inflammatory scores of the treatment groups (both low-dose and high-dose group) were markedly decreased compared to vehicle group, suggesting that berberine was able to decrease the infiltration of the inflammatory cells in asthmatic lung tissue. These results suggested that the NF- $\mathrm{KB}$ pathway inhibition by berberine can induce eosinophil apoptosis, thus reducing the inflammatory response. ${ }^{44,45}$ In addition, the amount of the inflammatory cells (neutrophil, eosinophils, lymphocytes, and macrophages) present in BALF of the group treated with berberine were markedly reduced compared to the vehicle group treated only with PBS $(\mathrm{P}<0.05)$. Overall, berberine was effective in suppressing the inflammatory response of ovalbumin-induced asthma in rat model with a dose-dependent manner via inhibition of the over-reactive NF- $\mathrm{kB}$ signalling pathway.

\subsection{Effect of berberine on pulmonary fibrosis}

Pulmonary fibrosis is normally associated with significant histological changes in the lung architecture following pathogenic fibrotic response. ${ }^{51}$ Based on the study carried out by Chitra et al., berberine reduces the histological changes mediated by bleomycin in the lung tissue of rat models. ${ }^{54}$ The Ashcroft quantitative pathological scoring of berberine treatment group was significantly lower than the bleomycin-induced rat model. ${ }^{54}$ Berberine also reduced the level of hydroxyproline, the recruitment of mast cell and histamine release in bleomycin-induced rat

model. ${ }^{54}$ These results suggest that berberine significantly reduces the accumulation and deposition of collagen, thus slowing the histological alterations in pulmonary fibrosis.

In addition to that, studies have also reported that suppression of NF- $\mathrm{BB}$ signalling pathway may alleviate the progress of pulmonary fibrosis. ${ }^{54,58,59}$ According to the study carried out by Chitra et al., the activation of NF- $\mathrm{kB}$ signalling pathway was significantly downregulated 
in the berberine treatment group compared to the bleomycin induced animal groups, suggesting that berberine is effective in suppressing NF- $\mathrm{BB}$ signalling pathway. ${ }^{54}$ The treatment group also showed significantly lower expression of iNOS, TGF- $\beta 1$ and TNF- $\alpha$, which most likely resulted from the downregulating NF- $\mathrm{kB}$ activation. The studies revealed that berberine inhibits TGF- $\beta 1$ via the activation of Smad 7 and inhibition of Smad 2/3 activation. ${ }^{89}$ In addition, the study by Javad-Mousavi et al., also revealed that the treatment groups that received an oral dose of either $100 \mathrm{mg} / \mathrm{kg}, 200 \mathrm{mg} / \mathrm{kg}$ or $400 \mathrm{mg} / \mathrm{kg}$ of the Berberis vulgaris fruit extract have significantly lower TGF- $\beta 1$ and TNF- $\alpha$ compared to the group which was exposed only to paraquat. ${ }^{90}$

Studies also showed that berberine can increase the levels of antioxidants in the body, consequently decreasing the oxidative stress. Based on previous studies, the induction of Nrf2 expression with antioxidants may be a therapeutic intervention to suppress the progression of pulmonary fibrosis. ${ }^{54,91}$ The study carried out by Chitra et al., prove that berberine treatment can reduce the levels of MDA, $\mathrm{OH}$ and $\mathrm{NO}$ in both BALF and lung tissue compared to bleomycininduced rat model. ${ }^{54}$ Besides that, the Nrf2 expression was also significantly higher in the berberine treated group, suggesting that the upregulation of the antioxidant levels was through the activation of $\mathrm{Nrf2}$ expression. ${ }^{54}$ Comparatively, berberine treatment group showed more efficacy in reducing oxidative stress at the preventive phase (0-14 days) compared to therapeutic phase (14-28 days), and this may be due to the nature of berberine that scavenge free radical produced, which inhibits the free radical chain reaction in the initial phase. ${ }^{54}$

Other than that, several studies have also suggested that berberine has the ability to reduce the levels of other inflammatory mediators. Based on the study carried out by Chitra et al., the level of MPO was increased in the bleomycin-induced control group and berberine treatment significantly reduce the level of MPO in both therapeutic and preventive aspects. ${ }^{54}$ 
This suggested that berberine can reduce neutrophil accumulation in the bleomycin-induced lung tissue. Besides, based on the study carried out by Javad-Mousavi et al., berberine treatment group also showed reduced pleiotropic cytokine, interleukin (IL)-6, which is involved in inflammation, haematopoiesis, and immune responses..$^{90,92}$ The study carried out by Guan et al., showed that berberine can increase the mRNA expression of human growth factor (HGF) and phosphatase and tensin homolog (PTEN) in the colon after oral administration..$^{93}$ However, the study shows that upregulation of HGF secretion is the key mechanism for the anti-fibrotic effect of berberine, where the increased HGF secretion is highly associated with the PPAR- $\gamma$ activation by berberine. ${ }^{93}$

\subsection{Effect of berberine in lung cancer}

A study conducted by Fang Zheng et al., reported that berberine reduces the cell viability of NSCLC cells (A549). Berberine disrupts the events in the $\mathrm{G}_{0} / \mathrm{G}_{1}$ phase of cell cycle in which the proportions of cells in the particular phase is found to be increased, indicating the initiation of cell cycle arrest in that phase. Furthermore, the presence of marked granular apoptotic bodies as well as increased rate of apoptosis are observed in berberine-treated cell lines. These conditions signify the ability of berberine to initiate apoptosis of NSCLC cells. ${ }^{94}$ Extracellular single-regulated kinase1/2 (ERK1/2) and p38 mitogen activated protein kinase (p38/MAPK) are both involved in cell apoptosis. Berberine, as shown in the study, increases the activation of both ERK1/2 and p38/MAPK, eventually increasing cell apoptosis. ${ }^{94,95}$ Forkhead homeobox type O3a (FOXO3a) is a tumour suppressor that is activated to upregulate the expression of proteins involved in cell cycle arrest and apoptosis. ${ }^{94,96}$ Berberine plays its role in suppressing tumour by increasing the activity of FOXO3a. ${ }^{94}$ 
In a study investigated by Santosh et al., it is proved that berberine causes a decrease in cell viability of NSCLC cells, eventually resulting in the inhibition of proliferation of NSCLC cells. Bax and Bak are examples of pro-apoptotic proteins, whereas, BcI-2 and BcI-x1 are antiapoptotic proteins. Berberine causes overexpression of pro-apoptotic proteins and underexpression of anti-apoptotic proteins. The regulation mechanisms of these proteins by berberine contribute to the apoptosis of NSCLC cells. Additionally, the cancer cells become more susceptible to the berberine-induced apoptosis due to the increased ratio of Bax:BcI-2 by berberine. Moreover, berberine is shown to disrupt the mitochondrial membrane potential. The disruption of the membrane potential of mitochondria plays a crucial role in the initiation of cell apoptosis. This condition is indicated by the liberation of Cytochrome $\mathrm{C}$ and Smac/DIABLO into the cytosol, which activate caspase-3, initiating cell death. Berberine is also found to directly increase the levels of Cytochrome $\mathrm{C}$ and Smac/DIABLO in the cytosol. Other than that, the fluorescence emission of JC-1 dye turns from red to green, signifying that the mitochondrial membrane potential has been disrupted. In berberine treated cell lines, the number of cells that displays green fluorescence is elevated, indicating the increased disruption of membrane potential of mitochondria by berberine. ${ }^{97}$ Hence, this shows the role of berberine in promoting cell apoptosis by interrupting the function of mitochondria of the cells.

Another study carried out by Zhu et al., showed the anti-cancer effect of berberine. Cells in the S phase of the cell cycle are represented by EdU-positive cells. Berberine significantly decreased the number of EdU-positive cells. This again shows that berberine is able to inhibit cell proliferation in lung cancer. Besides, berberine is also found to induce early and late cell apoptosis. Tumour spheroids that consist of cancer stem-cells imitate in-vivo tumour. Berberine is observed to not only reduce the number and size of the tumour spheroids, but also to inhibit 
the formation of these spheroids, indicating its ability to subside the formation of in-vivo tumours, such as NSCLC cells. ${ }^{98}$ In lung cancer, STAT3 is activated. Berberine, nonetheless, suppresses the activated form of STAT3 which causes the inhibition of cell growth and initiation of apoptosis. ${ }^{98,99}$

\section{Future perspectives and conclusion}

Preliminary studies have proven the anti-inflammatory effect of berberine in respiratory inflammatory diseases, that include COPD, asthma, pulmonary fibrosis and lung cancer. Based on the studies, berberine has been proven to activate the ERK1/2 \& p38 MAPK, caspase-3 and FOXO3a pathways while inhibiting the activation of NF- $\kappa \mathrm{B}$ and caspase- 1 signalling pathways. Several studies have shown that berberine treatment group reduces the level of inflammatory cytokines (TNF- $\alpha$, IL-6, IL-1B, MDA, OH and NO) as well as the inflammatory cell infiltration and collagen deposition. Berberine also decreased the activity of MPO and p38/MAPK, while reducing the mRNA expression of iNOS, TSLP and PTEN. The anti-apoptotic protein, BcI-2 \& BcI-x1 are downregulated in berberine treatment group whereas the pro-apoptotic proteins (Bax \& Bak) and Nrf2 expression were upregulated. These findings suggest the therapeutic potential of berberine in respiratory inflammatory diseases. However, there are several limitations with regard to the therapeutic applications of berberine. Firstly, there are not many clinical studies on berberine and secondly, the safety profile and toxicity of berberine are still not well-known due to limited number of studies, both preliminary and clinical. Berberine exerts its cytotoxic effect only on lung cancer cells but not on non-neoplastic cells such as human bronchial epithelial cells, suggesting that berberine may cause limited side effects on non-neoplastic cells. ${ }^{97}$ Thus, future studies are needed to further investigate the safety profile and toxicity of berberine, targeting inflammatory diseases in the respiratory system. 


\section{Conflict of interest}

The authors declared no conflict of interest.

\section{Acknowledgement}

The authors would like to thank International Medical University (IMU), Malaysia for providing the financial support for the project. Also, thanks to the Hunter Medical Research Institute (HMRI), The University of Newcastle, NSW 2308, Australia and the Discipline of Pharmacy,

Graduate School of Health, University of TechnologySydney, NSW 2007, Australia for providing necessary support.

\section{References}

1. Chen L, Deng H, Cui H, Fang J, Zuo Z, Deng J, et al. Inflammatory responses and inflammation-associated diseases in organs. Oncotarget. 2018 Jan;9(6):7204-18.

2. Libby P. Inflammatory Mechanisms: The Molecular Basis of Inflammation and Disease. Nutr Rev. 2008 Jun;65(suppl_3):S140-6.

3. Zhou Y, Hong Y, Huang H. Triptolide Attenuates Inflammatory Response in Membranous Glomerulo-Nephritis Rat via Downregulation of NF-\&amp;\#x03BA;B Signaling Pathway. Kidney Blood Press Res. 2016;41(6):901-10.

4. Moldoveanu B, Otmishi P, Jani P, Walker J, Sarmiento X, Guardiola J, et al. Inflammatory mechanisms in the lung. J Inflamm Res. 2009;2:1-11.

5. Leitch AE, Duffin R, Haslett C, Rossi AG. Relevance of granulocyte apoptosis to resolution of inflammation at the respiratory mucosa. Mucosal Immunol. 2008 
Sep;1(5):350-63.

6. Brusselle G, Bracke K. Targeting Immune Pathways for Therapy in Asthma and Chronic Obstructive Pulmonary Disease. Ann Am Thorac Soc. 2014 Dec;11(Supplement 5):S3228.

7. Wong J, Magun B, Wood L. Lung inflammation caused by inhaled toxicants: a review. Int J Chron Obstruct Pulmon Dis. 2016 Jun;1391.

8. Barnes PJ, Burney PGJ, Silverman EK, Celli BR, Vestbo J, Wedzicha JA, et al. Chronic obstructive pulmonary disease. Nat Rev Dis Prim [Internet]. 2015 Dec 3 [cited 2019 Aug 27];1(1):15076. Available from: http://www.nature.com/articles/nrdp201576

9. Barnes PJ. Inflammatory mechanisms in patients with chronic obstructive pulmonary disease. Vol. 138, Journal of Allergy and Clinical Immunology. Mosby Inc.; 2016. p. 1627.

10. Rabe KF, Watz H. Chronic obstructive pulmonary disease. Lancet [Internet]. 2017 May [cited 2019 Aug 27];389(10082):1931-40. Available from: https://inkinghub.elsevier.com/retrieve/pii/S0140673617312229

11. Evaluation I for HM and. Findings from the Global Burden of Disease Study 2017. Lancet. 2018;

12. American Thoracic Society PATIENT EDUCATION | INFORMATION SERIES www.thoracic.org CLIP AND COPY [Internet]. 2019. Available from: https://perf2ndwind.org/

13. Shin NR, Ko JW, Park SH, Cho YK, Oh SR, Ahn KS, et al. Protective effect of 
HwangRyunHaeDok-Tang water extract against chronic obstructive pulmonary disease induced by cigarette smoke and lipopolysaccharide in a mouse model. J Ethnopharmacol. 2017 Mar 22;200:60-5.

14. Shin IS, Park JW, Shin NR, Jeon CM, Kwon OK, Kim JS, et al. Melatonin reduces airway inflammation in ovalbumin-induced asthma. Immunobiology. 2014 Dec 1;219(12):901-8.

15. Cassini-Vieira P, Araújo FA, Da Costa Dias FL, Russo RC, Andrade SP, Teixeira MM, et al. INOS Activity Modulates Inflammation, Angiogenesis, and Tissue Fibrosis in Polyether-Polyurethane Synthetic Implants. Mediators Inflamm. 2015;2015.

16. Choudhury MG, Saha N. Induction of inducible nitric oxide synthase by lipopolysaccharide and the influences of cell volume changes, stress hormones and oxidative stress on nitric oxide efflux from the perfused liver of air-breathing catfish, Heteropneustes fossilis. PLoS One. 2016 Mar 1;11(3).

17. Snitker S, Xie K, Ryan KA, Yu D, Shuldiner AR, Mitchell BD, et al. Correlation of Circulating MMP-9 with White Blood Cell Count in Humans: Effect of Smoking. PLoS One. 2013 Jun 25;8(6).

18. Qaseem A, Wilt TJ, Weinberger SE, Hanania NA, Criner G, Molen T van der, et al. Diagnosis and Management of Stable Chronic Obstructive Pulmonary Disease: A Clinical Practice Guideline Update from the American College of Physicians, American College of Chest Physicians, American Thoracic Society, and European Respiratory Society. Ann Intern Med [Internet]. 2011 Aug 2 [cited 2019 Aug 27];155(3):179. Available from: http://annals.org/article.aspx?doi=10.7326/0003-4819-155-3-201108020-00008

19. PAUWELS RA, BUIST AS, CALVERLEY PMA, JENKINS CR, HURD SS. Global 
Strategy for the Diagnosis, Management, and Prevention of Chronic Obstructive Pulmonary Disease. Am J Respir Crit Care Med [Internet]. 2001 Apr 14 [cited 2019 Aug 27];163(5):1256-76. Available from: http://www.atsjournals.org/doi/abs/10.1164/ajrccm.163.5.2101039

20. Lahousse L, Verhamme KM, Stricker BH, Brusselle GG. Cardiac effects of current treatments of chronic obstructive pulmonary disease. The Lancet Respiratory Medicine. 2016.

21. Kudo M, Ishigatsubo Y, Aoki I. Pathology of asthma. Front Microbiol. 2013 Sep;4:263.

22. Kudo M, Ishigatsubo Y, Aoki I. Pathology of asthma. Front Microbiol [Internet]. 2013 Sep 10 [cited 2019 Aug 27];4:263. Available from: http://www.ncbi.nlm.nih.gov/pubmed/24032029

23. GBD 2015 Chronic Respiratory Disease Collaborators JB, Abajobir AA, Abate KH, Abera SF, Agrawal A, Ahmed MB, et al. Global, regional, and national deaths, prevalence, disability-adjusted life years, and years lived with disability for chronic obstructive pulmonary disease and asthma, 1990-2015: a systematic analysis for the Global Burden of Disease Study 2015. Lancet Respir Med. 2017 Sep;5(9):691-706.

24. Froidure A, Mouthuy J, Durham SR, Chanez P, Sibille Y, Pilette C. Asthma phenotypes and IgE responses. Eur Respir J [Internet]. 2016 Jan [cited 2019 Sep 24];47(1):304-19. Available from: http://www.ncbi.nlm.nih.gov/pubmed/26677936

25. Barnes PJ. Inhaled Corticosteroids. Pharmaceuticals (Basel) [Internet]. 2010 Mar 8 [cited 2019 Aug 27];3(3):514-40. Available from: http://www.ncbi.nlm.nih.gov/pubmed/27713266 
26. Xiao C, Puddicombe SM, Field S, Haywood J, Broughton-Head V, Puxeddu I, et al. Defective epithelial barrier function in asthma. J Allergy Clin Immunol [Internet]. 2011 Sep [cited 2019 Aug 27];128(3):549-556.e12. Available from: http://www.ncbi.nlm.nih.gov/pubmed/21752437

27. Moon P-D, Kim H-M. Thymic stromal lymphopoietin is expressed and produced by caspase-1/NF-kB pathway in mast cells. Cytokine [Internet]. 2011 Jun [cited 2019 Aug 29];54(3):239-43. Available from: http://www.ncbi.nlm.nih.gov/pubmed/21463955

28. Jeong H-J, Nam S-Y, Oh H-A, Han N-R, Kim Y-S, Moon P-D, et al. Interleukin-32induced thymic stromal lymphopoietin plays a critical role in macrophage differentiation through the activation of caspase-1 in vitro. Arthritis Res Ther [Internet]. 2012 Nov 28 [cited 2019 Aug 29];14(6):R259. Available from: http://arthritisresearch.biomedcentral.com/articles/10.1186/ar4104

29. Das J, Chen CH, Yang L, Cohn L, Ray P, Ray A. A critical role for NF-kappa B in GATA3 expression and TH2 differentiation in allergic airway inflammation. Nat Immunol [Internet]. 2001 Jan [cited 2019 Aug 29];2(1):45-50. Available from: http://www.ncbi.nlm.nih.gov/pubmed/11135577

30. Min HK, Kim S-M, Baek S-Y, Woo J-W, Park J-S, Cho M-L, et al. Anthocyanin Extracted from Black Soybean Seed Coats Prevents Autoimmune Arthritis by Suppressing the Development of Th17 Cells and Synthesis of Proinflammatory Cytokines by Such Cells, via Inhibition of NF-kB. Brand DD, editor. PLoS One [Internet]. 2015 Nov 6 [cited 2019 Aug 29];10(11):e0138201. Available from: http://www.ncbi.nlm.nih.gov/pubmed/26544846 
31. Zhang $\mathrm{T}$, Yang $\mathrm{S}, \mathrm{Du}$ J, Jinfu Y, Shumin W. Platycodin D Attenuates Airway Inflammation in a Mouse Model of Allergic Asthma by Regulation NF-kB Pathway. Inflammation [Internet]. 2015 Jun 13 [cited 2019 Aug 29];38(3):1221-8. Available from: http://www.ncbi.nlm.nih.gov/pubmed/25578175

32. Zhao J, Lee TH, Corrigan Kirsty Mallett C, Cousins D, Robinson D, Sun Ying G, et al. Chemokines and Disease Severity Correlates with Expression of Th2-Attracting Is Increased in Asthmatic Airways and Thymic Stromal Lymphopoietin Expression. 2017 [cited 2019 Aug 28]; Available from: http://www.jimmunol.org/content/174/12/8183

33. Han H, Xu W, Headley MB, Jessup HK, Lee KS, Omori M, et al. Thymic stromal lymphopoietin (TSLP)-mediated dermal inflammation aggravates experimental asthma. Mucosal Immunol [Internet]. 2012 May 22 [cited 2019 Aug 28];5(3):342-51. Available from: http://www.nature.com/articles/mi201214

34. He R, Geha RS. Thymic stromal lymphopoietin. Ann N Y Acad Sci [Internet]. 2010 Jan [cited 2019 Aug 28];1183(1):13-24. Available from: http://www.ncbi.nlm.nih.gov/pubmed/20146705

35. Rochman Y, Leonard WJ. Thymic stromal lymphopoietin: a new cytokine in asthma. Curr Opin Pharmacol [Internet]. 2008 Jun [cited 2019 Aug 28];8(3):249-54. Available from: http://www.ncbi.nlm.nih.gov/pubmed/18450510

36. Moon P-D, Choi I-H, Kim H-M. Berberine inhibits the production of thymic stromal lymphopoietin by the blockade of caspase- $1 / \mathrm{NF}-\mathrm{kB}$ pathway in mast cells. Int Immunopharmacol [Internet]. 2011 Nov [cited 2019 Aug 28];11(11):1954-9. Available from: http://www.ncbi.nlm.nih.gov/pubmed/21856447 
37. Shan L, Redhu NS, Saleh A, Halayko AJ, Chakir J, Gounni AS. Thymic stromal lymphopoietin receptor-mediated IL-6 and CC/CXC chemokines expression in human airway smooth muscle cells: role of MAPKs (ERK1/2, p38, and JNK) and STAT3 pathways. J Immunol [Internet]. 2010 Jun 15 [cited 2019 Aug 28];184(12):7134-43. Available from: http://www.ncbi.nlm.nih.gov/pubmed/20483734

38. Rochman Y, Leonard WJ. The Role of Thymic Stromal Lymphopoietin in CD8 ${ }^{+}$T Cell Homeostasis. J Immunol [Internet]. 2008 Dec 1 [cited 2019 Sep 24];181(11):7699-705. Available from: http://www.ncbi.nlm.nih.gov/pubmed/19017958

39. Redhu NS, Gounni AS. Function and mechanisms of TSLP/TSLPR complex in asthma and COPD. Clin Exp Allergy [Internet]. 2012 Jul [cited 2019 Sep 24];42(7):994-1005. Available from: http://www.ncbi.nlm.nih.gov/pubmed/22168549

40. Roan F, Bell BD, Stoklasek TA, Kitajima M, Han H, Ziegler SF. The multiple facets of thymic stromal lymphopoietin (TSLP) during allergic inflammation and beyond. J Leukoc Biol [Internet]. 2012 Jun [cited 2019 Sep 24];91(6):877-86. Available from: http://www.ncbi.nlm.nih.gov/pubmed/22442496

41. Li Z, Zheng J, Zhang N, Li C. Berberine improves airway inflammation and inhibits NF$\kappa \mathrm{B}$ signaling pathway in an ovalbumin-induced rat model of asthma. J Asthma [Internet]. 2016 Nov 25 [cited 2019 Aug 28];53(10):999-1005. Available from: http://www.ncbi.nlm.nih.gov/pubmed/27175622

42. Pelaia G, Vatrella A, Busceti MT, Gallelli L, Calabrese C, Terracciano R, et al. Cellular Mechanisms Underlying Eosinophilic and Neutrophilic Airway Inflammation in Asthma. Mediators Inflamm [Internet]. 2015 [cited 2019 Aug 29];2015:1-8. Available from: 
http://www.ncbi.nlm.nih.gov/pubmed/25878402

43. Kankaanranta H, Lindsay MA, Giembycz MA, Zhang X, Moilanen E, Barnes PJ. Delayed eosinophil apoptosis in asthma. J Allergy Clin Immunol [Internet]. 2000 Jul [cited 2019 Aug 29];106(1):77-83. Available from: http://www.ncbi.nlm.nih.gov/pubmed/10887309

44. Park YM, Bochner BS. Eosinophil Survival and Apoptosis in Health and Disease. Allergy, Asthma Immunol Res [Internet]. 2010 Apr [cited 2019 Aug 29];2(2):87. Available from: http://www.ncbi.nlm.nih.gov/pubmed/20358022

45. Fujihara S, Jaffray E, Farrow SN, Rossi AG, Haslett C, Hay RT. Inhibition of NF-kB by a cell permeable form of IкB $\alpha$ induces apoptosis in eosinophils. Biochem Biophys Res Commun [Internet]. 2005 Jan 21 [cited 2019 Aug 29];326(3):632-7. Available from: http://www.ncbi.nlm.nih.gov/pubmed/15596146

46. Wilson MS, Wynn TA. Pulmonary fibrosis: pathogenesis, etiology and regulation. Mucosal Immunol [Internet]. 2009 Mar [cited 2019 Aug 27];2(2):103-21. Available from: http://www.ncbi.nlm.nih.gov/pubmed/19129758

47. Barratt S, Creamer A, Hayton C, Chaudhuri N. Idiopathic Pulmonary Fibrosis (IPF): An Overview. J Clin Med [Internet]. 2018 Aug 6 [cited 2019 Aug 27];7(8):201. Available from: http://www.ncbi.nlm.nih.gov/pubmed/30082599

48. Sharif R. Overview of idiopathic pulmonary fibrosis (IPF) and evidence-based guidelines. Am J Manag Care [Internet]. 2017 Jul [cited 2019 Aug 27];23(11 Suppl):S176-82. Available from: http://www.ncbi.nlm.nih.gov/pubmed/28978212

49. Hutchinson J, Fogarty A, Hubbard R, McKeever T. Global incidence and mortality of 
idiopathic pulmonary fibrosis: a systematic review. Eur Respir J [Internet]. 2015 Sep 1 [cited 2019 Aug 28];46(3):795-806. Available from: http://www.ncbi.nlm.nih.gov/pubmed/25976683

50. Hutchinson J, Fogarty A, Hubbard R, McKeever T. Global incidence and mortality of idiopathic pulmonary fibrosis: a systematic review. Eur Respir J. 2015 Sep;46(3):795806.

51. Wolters PJ, Collard HR, Jones KD. Pathogenesis of idiopathic pulmonary fibrosis. Annu Rev Pathol [Internet]. 2014 [cited 2019 Sep 2];9:157-79. Available from: http://www.ncbi.nlm.nih.gov/pubmed/24050627

52. Kliment CR, Englert JM, Crum LP, Oury TD. A novel method for accurate collagen and biochemical assessment of pulmonary tissue utilizing one animal. Int J Clin Exp Pathol [Internet]. 2011 Apr [cited 2019 Sep 2];4(4):349-55. Available from: http://www.ncbi.nlm.nih.gov/pubmed/21577320

53. Todd NW, Luzina IG, Atamas SP. Molecular and cellular mechanisms of pulmonary fibrosis. Fibrogenesis Tissue Repair [Internet]. 2012 Jul 23 [cited 2019 Sep 2];5(1):11. Available from: http://www.ncbi.nlm.nih.gov/pubmed/22824096

54. Chitra P, Saiprasad G, Manikandan R, Sudhandiran G. Berberine attenuates bleomycin induced pulmonary toxicity and fibrosis via suppressing NF- $\mathrm{kB}$ dependant TGF- $\beta$ activation: A biphasic experimental study. Toxicol Lett [Internet]. 2013 May 23 [cited 2019 Aug 29];219(2):178-93. Available from: http://www.ncbi.nlm.nih.gov/pubmed/23523906

55. Pesci A, Bertorelli G, Gabrielli M, Olivieri D. Mast Cells in Fibrotic Lung Disorders. 
Chest [Internet]. 1993 Apr [cited 2019 Sep 2];103(4):989-96. Available from: http://www.ncbi.nlm.nih.gov/pubmed/8131513

56. Cantin AM, Hubbard RC, Crystal RG. Glutathione Deficiency in the Epithelial Lining Fluid of the Lower Respiratory Tract in Idiopathic Pulmonary Fibrosis. Am Rev Respir Dis [Internet]. 1989 Feb [cited 2019 Aug 31];139(2):370-2. Available from: http://www.ncbi.nlm.nih.gov/pubmed/2913886

57. Beeh KM, Beier J, Haas IC, Kornmann O, Micke P, Buhl R. Glutathione deficiency of the lower respiratory tract in patients with idiopathic pulmonary fibrosis. Eur Respir J [Internet]. 2002 Jun 1 [cited 2019 Aug 31];19(6):1119-23. Available from: http://www.ncbi.nlm.nih.gov/pubmed/12108866

58. Khalil N, Greenberg AH. The role of TGF-beta in pulmonary fibrosis. Ciba Found Symp [Internet]. 1991 [cited 2019 Sep 1];157:194-207; discussion 207-11. Available from: http://www.ncbi.nlm.nih.gov/pubmed/1712697

59. Li X, Li N, Ban C, Zhu M, Xiao B, Dai H. Idiopathic pulmonary fibrosis in relation to gene polymorphisms of transforming growth factor- $\beta 1$ and plasminogen activator inhibitor 1. Chin Med J (Engl) [Internet]. 2011 Jul 5 [cited 2019 Sep 1];124(13):1923-7. Available from: http://www.ncbi.nlm.nih.gov/pubmed/22088447

60. Giri SN, Biring I, Nguyen T, Wang Q, Hyde DM. Abrogation of bleomycin-induced lung fibrosis by nitric oxide synthase inhibitor, aminoguanidine in mice. Nitric Oxide [Internet]. 2002 Sep 1 [cited 2019 Sep 2];7(2):109-18. Available from: https://www.sciencedirect.com/science/article/pii/S1089860302001027?via\%3Dihub

61. Daniil ZD, Papageorgiou E, Koutsokera A, Kostikas K, Kiropoulos T, Papaioannou AI, et 
al. Serum levels of oxidative stress as a marker of disease severity in idiopathic pulmonary fibrosis. Pulm Pharmacol Ther [Internet]. 2008 Feb [cited 2019 Sep 2];21(1):26-31. Available from: https://linkinghub.elsevier.com/retrieve/pii/S1094553906001143

62. Fois AG, Paliogiannis P, Sotgia S, Mangoni AA, Zinellu E, Pirina P, et al. Evaluation of oxidative stress biomarkers in idiopathic pulmonary fibrosis and therapeutic applications: a systematic review. Respir Res [Internet]. 2018 [cited 2019 Sep 2];19(1):51. Available from: http://www.ncbi.nlm.nih.gov/pubmed/29587761

63. Sato S, Yanagihara T, Kolb MRJ. Therapeutic targets and early stage clinical trials for pulmonary fibrosis. Expert Opin Investig Drugs [Internet]. 2019 Jan 2 [cited 2019 Aug 27];28(1):19-28. Available from: https://www.tandfonline.com/doi/full/10.1080/13543784.2019.1554054

64. Bray F, Ferlay J, Soerjomataram I, Siegel RL, Torre LA, Jemal A. Global cancer statistics 2018: GLOBOCAN estimates of incidence and mortality worldwide for 36 cancers in 185 countries. CA Cancer J Clin. 2018;

65. Herbst RS, Heymach J V., Lippman SM. Molecular origins of cancer: Lung cancer. New England Journal of Medicine. 2008.

66. Gomes M, Teixeira AL, Coelho A, Araújo A, Medeiros R. The role of inflammation in lung cancer. Adv Exp Med Biol. 2014;

67. Hanahan D, Weinberg RA. Hallmarks of cancer: The next generation. Vol. 144, Cell. 2011. p. 646-74.

68. Fang Y, Wang J, Wang G, Zhou C, Wang P, Zhao S, et al. Inactivation of p38 MAPK 
contributes to stem cell-like properties of non-small cell lung cancer. Oncotarget. 2017;

69. Yin ZJ, Jin FG, Liu TG, Fu EQ, Xie YH, Sun RL. Overexpression of STAT3 potentiates growth, survival, and radioresistance of non-small-cell lung cancer (NSCLC) cells. J Surg Res. 2011;

70. Kalemkerian G. Small Cell Lung Cancer. Semin Respir Crit Care Med [Internet]. 2016 Oct 12 [cited 2019 Aug 28];37(05):783-96. Available from: http://www.thiemeconnect.de/DOI/DOI?10.1055/s-0036-1592116

71. Morabito A, Carillio G, Daniele G, Piccirillo MC, Montanino A, Costanzo R, et al. Treatment of small cell lung cancer. Crit Rev Oncol Hematol [Internet]. 2014 Sep [cited 2019 Aug 28];91(3):257-70. Available from: https://linkinghub.elsevier.com/retrieve/pii/S1040842814000523

72. Waqar SN, Morgensztern D. Treatment advances in small cell lung cancer (SCLC). Vol. 180, Pharmacology and Therapeutics. Elsevier Inc.; 2017. p. 16-23.

73. Zappa C, Mousa SA. Non-small cell lung cancer: Current treatment and future advances. Transl Lung Cancer Res. 2016 Jun 1;5(3):288-300.

74. Li F-S, Weng J-K. Demystifying traditional herbal medicine with modern approach. Nat Plants [Internet]. 2017 Aug 31 [cited 2019 Aug 21];3(8):17109. Available from: http://www.ncbi.nlm.nih.gov/pubmed/28758992

75. Abou El-Soud N. Herbal medicine in ancient Egypt. J Med plant Res [Internet]. 2010 [cited 2019 Aug 21];4(2):82-6. Available from: https://www.researchgate.net/publication/228634623_Herbal_medicine_in_ancient_Egypt 
76. Zhang Q, Cai L, Zhong G, Luo W. [Simultaneous determination of jatrorrhizine, palmatine, berberine, and obacunone in Phellodendri Amurensis Cortex by RP-HPLC]. Zhongguo Zhong Yao Za Zhi [Internet]. 2010 Aug [cited 2019 Aug 20];35(16):2061-4. Available from: http://www.ncbi.nlm.nih.gov/pubmed/21046728

77. Chander Junior Scientific Assistant V, Aswal J, Dobhal R, Uniyal D, Chander V. A review on Pharmacological potential of Berberine; an active component of Himalayan Berberis aristata [Internet]. Vol. 6, The Journal of Phytopharmacology. 2017 [cited 2019 Aug 20]. Available from: www.phytopharmajournal.com

78. Schor J. Clinical Applications for Berberine: Potential therapeutic applications in metabolic syndrome, type 2 diabetes, and dyslipidemia. Nat Med J [Internet]. 2012 [cited 2019 Aug 20];4(12). Available from: https://www.naturalmedicinejournal.com/print/587

79. Hu X, Zhang Y, Xue Y, Zhang Z, Wang J. Berberine is a potential therapeutic agent for metabolic syndrome via brown adipose tissue activation and metabolism regulation. Am J Transl Res [Internet]. 2018 [cited 2019 Aug 20];10(11):3322-9. Available from: http://www.ncbi.nlm.nih.gov/pubmed/30662589

80. Singh IP, Mahajan S. Berberine and its derivatives: a patent review $(2009-2012)$. Expert Opin Ther Pat [Internet]. 2013 Feb 12 [cited 2019 Aug 20];23(2):215-31. Available from: http://www.ncbi.nlm.nih.gov/pubmed/23231038

81. Tan H-L, Chan K-G, Pusparajah P, Duangjai A, Saokaew S, Mehmood Khan T, et al. Rhizoma Coptidis: A Potential Cardiovascular Protective Agent. Front Pharmacol [Internet]. 2016 Oct 7 [cited 2019 Aug 21];7:362. Available from: http://www.ncbi.nlm.nih.gov/pubmed/27774066 
82. Pang B, Yu X-T, Zhou Q, Zhao T-Y, Wang H, Gu C-J, et al. Effect of Rhizoma coptidis (Huang Lian) on Treating Diabetes Mellitus. Evidence-Based Complement Altern Med [Internet]. 2015 [cited 2019 Aug 21];2015:1-10. Available from: http://www.ncbi.nlm.nih.gov/pubmed/26508987

83. Yang S. The divine farmer's materia medica: a translation of the Shen Nong Ben Cao Jing [Internet]. 1st ed. Boulder CO: Blue Poppy Press; 1998 [cited 2019 Aug 20]. 198 p. Available from: https://www.worldcat.org/title/divine-farmers-materia-medica-atranslation-of-the-shen-nong-ben-cao-jing/oclc/41048949

84. Mazumder PM, Das S, Das S, Das MK. Phyto-pharmacology of Berberis aristata DC: a review. J Drug Deliv Ther [Internet]. 2011 Dec 10 [cited 2019 Aug 20];1(2). Available from: http://jddtonline.info/index.php/jddt/article/view/34

85. Kim SG, Poudel A, Kim YK, Jo HK, Jung HJ. Development of simultaneous analysis for marker constituents in Hwangryunhaedok-tang and its application in commercial herbal formulas. J Nat Med. 2013 Apr;67(2):390-8.

86. Lin K, Liu S, Shen Y, Li Q. Berberine attenuates cigarette smoke-induced acute lung inflammation. Inflammation. 2013 Oct;36(5):1079-86.

87. Li CL, Tan LH, Wang YF, Luo CD, Chen H Bin, Lu Q, et al. Comparison of antiinflammatory effects of berberine, and its natural oxidative and reduced derivatives from Rhizoma Coptidis in vitro and in vivo. Phytomedicine. 2019 Jan 1;52:272-83.

88. Xu D, Wan C, Wang T, Tian P, Li D, Wu Y, et al. Berberine attenuates cigarette smokeinduced airway inflammation and mucus hypersecretion in mice. Int J Clin Exp Med [Internet]. 2015 [cited 2019 Aug 29];8(6):8641-7. Available from: 
http://www.ncbi.nlm.nih.gov/pubmed/26309516

89. Chitra P, Saiprasad G, Manikandan R, Sudhandiran G. Berberine inhibits Smad and nonSmad signaling cascades and enhances autophagy against pulmonary fibrosis. J Mol Med [Internet]. 2015 Sep 17 [cited 2019 Aug 29];93(9):1015-31. Available from: http://www.ncbi.nlm.nih.gov/pubmed/25877860

90. Javad-Mousavi SA, Hemmati AA, Mehrzadi S, Hosseinzadeh A, Houshmand G, Rashidi Nooshabadi MR, et al. Protective effect of Berberis vulgaris fruit extract against Paraquatinduced pulmonary fibrosis in rats. Biomed Pharmacother [Internet]. 2016 Jul [cited 2019 Sep 1];81:329-36. Available from: http://www.ncbi.nlm.nih.gov/pubmed/27261610

91. Kang ES, Woo IS, Kim HJ, Eun SY, Paek KS, Kim HJ, et al. Up-regulation of aldose reductase expression mediated by phosphatidylinositol 3-kinase/Akt and Nrf2 is involved in the protective effect of curcumin against oxidative damage. Free Radic Biol Med [Internet]. 2007 Aug 15 [cited 2019 Sep 2];43(4):535-45. Available from: http://www.ncbi.nlm.nih.gov/pubmed/17640564

92. Tanaka T, Narazaki M, Kishimoto T. IL-6 in inflammation, immunity, and disease. Cold Spring Harb Perspect Biol [Internet]. 2014 Sep 4 [cited 2019 Sep 2];6(10):a016295. Available from: http://www.ncbi.nlm.nih.gov/pubmed/25190079

93. Guan C, Qiao S, Lv Q, Cao N, Wang K, Dai Y, et al. Orally administered berberine ameliorates bleomycin-induced pulmonary fibrosis in mice through promoting activation of PPAR- $\gamma$ and subsequent expression of HGF in colons. Toxicol Appl Pharmacol [Internet]. 2018 Mar 15 [cited 2019 Aug 29];343:1-15. Available from: http://www.ncbi.nlm.nih.gov/pubmed/29408570 
94. Zheng F, Tang Q, Wu J, Zhao S, Liang Z, Li L, et al. P38 $\alpha$ MAPK-mediated induction and interaction of FOXO3a and p53 contribute to the inhibited-growth and inducedapoptosis of human lung adenocarcinoma cells by berberine. J Exp Clin Cancer Res. 2014 Apr 26;33(1).

95. Khajah MA, Mathew PM, Luqmani YA. Inhibitors of PI3K/ERK1/2/p38 MAPK show preferential activity against endocrine-resistant breast cancer cells. Oncol Res. 2017;25(8):1283-95.

96. Liang Z, Wang X, Xu X, Xie B, Ji A, Meng S, et al. MicroRNA-608 inhibits proliferation of bladder cancer via AKT/FOXO3a signaling pathway. Mol Cancer. 2017 May 26;16(1).

97. Katiyar SK, Meeran SM, Katiyar N, Akhtar S. P53 cooperates berberine-induced growth inhibition and apoptosis of non-small cell human lung cancer cells in vitro and tumor xenograft growth in vivo. Mol Carcinog. 2009 Jan;48(1):24-37.

98. Zhu T, Li LL, Xiao GF, Luo QZ, Liu QZ, Yao KT, et al. Berberine Increases Doxorubicin Sensitivity by Suppressing STAT3 in Lung Cancer. Am J Chin Med. 2015 Oct $1 ; 43(7): 1487-502$.

99. Yin ZJ, Jin FG, Liu TG, Fu EQ, Xie YH, Sun RL. Overexpression of STAT3 potentiates growth, survival, and radioresistance of non-small-cell lung cancer (NSCLC) cells. J Surg Res. 2011 Dec;171(2):675-83. 


\section{HIGHLIGHTS}

- Inflammatory responses play a crucial role in chronic respiratory diseases

- Berberine functions through the NF-kB, ERK1/2 and p38 MAPK pathways

- Berberine causes a decrease in pro-inflammatory cytokine levels

- Berberine improves the histological changes in the lung tissue of rat models

- Berberine suppresses tumours by increasing the activity of FOXO3a 


\section{Immunological axis of Berberine in Managing Inflammation Underlying Chronic Respiratory Inflammatory Diseases}

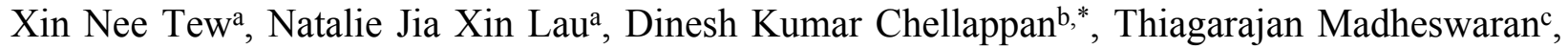
Farrukh Zeeshan $^{\mathrm{c}}$, Murtaza M. Tambuwala ${ }^{\mathrm{d}}$, Alaa AA. Aljabalie, Sri Renukadevi Balusamy ${ }^{\mathrm{f}}$, Haribalan Perumalsamy ${ }^{\mathrm{g}}$, Gaurav Gupta ${ }^{\mathrm{h}}$, Brian G. Oliver ${ }^{\mathrm{i}, \mathrm{j}}$, Alan Hsul, Peter Wark ${ }^{1}$, Karosham Reddy,j, Ridhima Wadhwa ${ }^{\mathrm{k}, \mathrm{l}}$, Philip Michael Hansbro ${ }^{\mathrm{k}, 1, \mathrm{~m}}$, Kamal Dua $^{\mathrm{k}, 1, \mathrm{~m}, \mathrm{n}^{*}}$

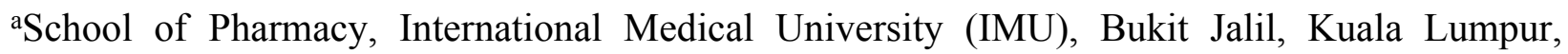
57000, Malaysia

bepartment of Life Sciences, School of Pharmacy, International Medical University (IMU), Bukit Jalil, Kuala Lumpur, 57000, Malaysia

'Department of Pharmaceutical Technology, School of Pharmacy, International Medical University (IMU), Bukit Jalil, Kuala Lumpur, 57000, Malaysia

${ }^{\mathrm{d} S c h o o l ~ o f ~ P h a r m a c y ~ a n d ~ P h a r m a c e u t i c a l ~ S c i e n c e s, ~ U l s t e r ~ U n i v e r s i t y, ~ C o l e r a i n e, ~ C o u n t y, ~}$ Londonderry, BT52 1SA, Northern Ireland, United Kingdom

eFaculty of Pharmacy, Department of Pharmaceutical Sciences, Yarmouk University, Irbid 21163, Jordan

fDepartment of Food Science and Biotechnology, Sejong University, Gwangjin-gu, Seoul 05006, Republic of Korea

gGraduate School of Biotechnology, College of Life Sciences, Kyung Hee University, Yongin 446-701, Republic of Korea 
hSchool of Pharmacy, Suresh Gyan Vihar University, Jagatpura 302017, Mahal Road, Jaipur, India

iSchool of Life Sciences, Faculty of Science, University of Technology Sydney (UTS), Ultimo, NSW, 2007, Australia

${ }^{j}$ Respiratory Cellular and Molecular Biology Group, Woolcock Institute of Medical Research, Sydney, Australia

kDiscipline of Pharmacy, Graduate School of Health, University of Technology Sydney (UTS), Ultimo, NSW, 2007, Australia

'School of Life Sciences, Faculty of Science, University of Technology Sydney (UTS), Ultimo, NSW, 2007, Australia

mPriority Research Centre for Healthy Lungs, Hunter Medical Research Institute (HMRI) \& School of Biomedical Sciences and Pharmacy, The University of Newcastle (UoN), Callaghan, NSW, 2308, Australia

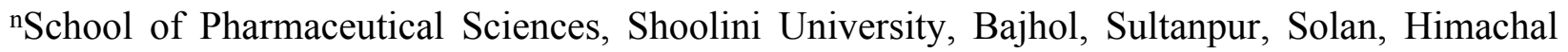
Pradesh, 173 229, India

*Corresponding authors

1. Dr Dinesh Kumar Chellappan

Email address: dineshkumarchellappan.imu@gmail.com

2. Dr Kamal Dua

Email address: kamalpharmacist02@gmail.com 


\begin{abstract}
Inflammatory responses play a remarkable role in the mechanisms of acute and chronic respiratory diseases such as chronic obstructive pulmonary disease (COPD), asthma, pulmonary fibrosis and lung cancer. Currently, there is a resurgence in the use of drugs from natural sources for various ailments as potent therapeutics. Berberine, an alkaloid prominent in the Chinese traditional system of medicine has been reported to exert therapeutic properties in various diseases. Nevertheless, the number of studies focusing on the curative potential of berberine in inflammatory diseases involving the respiratory system is limited. In this review, we have attempted to discuss the reported anti-inflammatory properties of berberine that function through several pathways such as, the NF-кB, ERK1/2 and p38 MAPK pathways which affect several pro-inflammatory cytokines in the pathophysiological processes involved in chronic respiratory diseases. This review would serve to provide valuable information to researchers who work in this field and a new direction in the field of drug discovery with respect to respiratory diseases.
\end{abstract}

Keywords: Berberine; inflammatory diseases; respiratory diseases; COPD; asthma; pulmonary fibrosis; lung cancer.

\title{
1. Introduction
}

Inflammation is a defense response of the human body against injury or infectious agents with the primary intent to remove noxious stimuli and to promote healing. ${ }^{1,2}$ Signs and symptoms such as rubor, calor, tumor, dolor, and functio laesa, which are also known as redness, heat, swelling, pain and loss of function respectively are associated with the cellular and molecular events that occur during an inflammatory response. ${ }^{2}$ Ideally, acute inflammation resolves when the body homeostasis has been restored, after the injury or the invaded stimuli..$^{1,3}$ 
However, uncontrolled and untreated inflammation can progress into various inflammatory diseases.

Inflammatory diseases that involve the respiratory system may impair gas exchange, resulting in hypoxia and eventually leading to death. The lungs are being constantly exposed to pathogens, allergens, irritants or toxic molecules in the atmosphere and thus, the pulmonary defense system is vital in protecting the integrity and function of the respiratory system. The balance between the inflammatory responses and the anti-inflammatory mechanism, therefore, are important in regulating lung homeostasis. ${ }^{4}$ Acute respiratory inflammation involves neutrophils while, chronic lung inflammation involves lymphocytes and macrophages. In acute pulmonary inflammation, chemotactic factors are expressed by activated endothelial cells, resulting in a chemotactic gradient that first causes the migration of neutrophils and then the production of chemokines. ${ }^{4}$ Acute respiratory distress syndrome (ARDS) and pneumonia are notable examples that results from acute pulmonary inflammation. ${ }^{5-7}$ Chronic respiratory inflammation, on the other hand, involves lymphocytes and macrophages and is the direct result of incomplete recovery from acute lung inflammation and its responses. In addition, chronic inflammation also includes the presence of necrotic debris and apoptotic cells which are the resultant products of the acute injury. ${ }^{4}$ Chronic lung inflammation is often associated with chronic obstructive pulmonary disease (COPD), asthma, lung cancer and pulmonary fibrosis. ${ }^{5-7}$

Plants have been widely used for medical purposes for thousands of years. Plants are known to relieve symptoms of various ailments. ${ }^{74}$ In several traditional systems of medicine namely, Ayurveda, Traditional Chinese Medicine (TCM) and Egyptian medicine, plants including herbs, are utilised for their medicinal properties for treating illnesses, improving health and disease prevention. ${ }^{74}$ Herbal medicines in different forms target specific parts of the human 
body. ${ }^{75}$ For instance, raw garlic aids in the respiratory system, treating asthma, whereas, mashed vinegar-macerated garlic relieves toothaches and sore throats. ${ }^{75}$ In the current era, herbal medicines have been massively replaced by modern drugs. Nonetheless, the use of herbal medicines is highly exercised throughout the world.

Berberine is a benzylisoquinoline alkaloid (Figure 1) that can be normally found in the barks, stems, rhizomes or roots of various plant sources, including Arcangelisia flava (Yellow Fruit Moonseed), Berberis aquifolium (Oregon grape), Rhizoma coptidis ('Huang Lian'), Berberis vulgaris (Barberry), Coptis chinensis (Coptis or Goldenthread), Berberis aristata (Tree Turmeric), Hydrastis Canadensis (Goldenseal), Phellodendron chinense (Chinese Cork Tree) and Phellodendron amurense (Amur cork tree). ${ }^{76-82}$ The first recorded use of berberine (Rhizoma coptidis) as folk medicine can be traced back to A.D. 200 in China, used by the father of Chinese medicine, Shennong. ${ }^{81-83}$ Rhizoma coptidis was traditionally used to treat the complications associated with diabetes for over 1500 years. Berberine containing plants were also widely used in ancient Ayurvedic medicine due to its anti-protozoal and anti-microbial activities. ${ }^{80}$ Among the various sources of berberine, Berberis aristata was widely mentioned in the scriptures of Ayurveda, Sushruta and Charaka. ${ }^{84}$ Berberis aristata was also used in homeopathy to treat diseases back in time. Some of the most common marketed formulations containing berberine that are sold in the US are listed in Table 2. Berberine, when subjected to pharmacokinetic studies, using rat plasma revealed the presence of four major metabolites, namely, berberrubine, thalifendine, demethyleneberberine, and jatrorrhizine, as free and glucuronide conjugates.

\subsection{Chronic obstructive pulmonary disease (COPD)}

Chronic obstructive pulmonary disease (COPD) primarily corresponds to severe and prolonged inflammation of the airways. Tobacco smoke is recognised as one of the primary 
causes of COPD, nevertheless, air pollution, chemical fumes, poisonous gases, particlates and dust are also associated with disease onset. ${ }^{8-10}$ Based on the Global Burden Disease Study 2017, COPD is one of the seven diseases that contributes to more than one million deaths each around the world. ${ }^{11}$ People with COPD either experience chronic bronchiolitis, emphysema or a combination of both. Chronic bronchiolitis involves severe inflammation and swelling of the airways, eventually leading to a decreased size of the airways. Emphysema, on the other hand, is specifically characterized as the loss of elasticity of the alveoli wall which prevents the emptying of air and therefore, results in breathing difficulty. This condition, eventually over a period of time, culminates in shortness of breath (dyspnea). ${ }^{8-10,12}$ In COPD, there is an elevation in the levels of neutrophils and macrophages. Barnes et al., reported that activated macrophages release high levels of inflammatory mediators such as IL-6, IL-1 $\beta$ and TNF- $\alpha .{ }^{9}$ Exposures to cigarette smoke (CS) and lipopolysaccharides (LPS) remarkably elevate inflammatory cell counts, specifically the neutrophil counts. Furthermore, CS and LPS exposures increase the levels of pro-inflammatory cytokines namely, TNF- $\alpha$, IL-1 $\beta$ and IL-6. Exposure to LPS along with elevated TNF- $\alpha$ level increase phosphorylation of the transcription factor, nuclear factor- $\mathrm{\kappa B}$ (NF-kB), causing the degradation of I $\mathrm{B} \alpha$. This then causes production of induced nitric oxide synthase (iNOS) and matrix metalloproteinases (MMPs). ${ }^{13,14}$ Expression of iNOS induced by cytokines further causes the production of nitric oxide, promoting inflammatory response of pulmonary cells. ${ }^{15,16}$ Furthermore, MMPs are endopeptidases that destroy the matrix proteins, leading to the destruction of the normal structure of alveoli, exacerbating pulmonary inflammation and eventually inducing emphysema. All these factors contribute to a loss in the lung function. ${ }^{13,17}$ Based on the American College of Physicians Clinical Practice guidelines, the first-line management of COPD is monotherapy with either long-acting $\beta$-agonist (LABA) or 
inhaled anticholinergic. ${ }^{18,19}$ However, treatment with LABA has been reported to induce several adverse effects including tremor, palpitation, arrythmias and cardiac ischaemia. ${ }^{20}$

\subsection{Asthma}

Asthma is the result of reversible airway obstruction, resulting from airway inflammation and hyperresponsiveness. ${ }^{21}$ The clinical symptoms of asthma involve shortness of breath, wheezing, chest tightness and sometimes cough, where death can occur if the symptoms do not relieve on time. ${ }^{22}$ According to a systematic analysis by Abajobir et al., in 2015, asthma has the highest prevalence compared to other chronic respiratory diseases throughout the world. ${ }^{23}$ However, the death rate of asthma had decreased $26.7 \%$ as compared from the year 1990, with $1 \%$ of global disability-adjusted life years (DALYs) from the earlier $2.6 \%$ of global DALYs. ${ }^{23}$ Asthma is a hyper-responsive allergic reaction in the airways that is normally acquired in all ages. Atopic asthma is commonly acquired in the childhood, where the airway inflammation involves over-reaction of specific immunoglobulin E (IgE) antibodies. ${ }^{24}$

Although asthma is still incurable, inhaled corticosteroids (ICS) are the first line management for patient with persistent asthma. ${ }^{25}$ This is because ICS are effective in controlling asthma exacerbation even at a low dose. ${ }^{25}$ However, ICS work only by suppressing the inflammatory reactions in the airway, without providing a perfect solution for asthma cure. ${ }^{25}$ Other than that, high dose use of ICS in patients with severe asthma might be associated with local and systemic side effect such as oral candidiasis, bruising and cataracts. ${ }^{25}$

In asthmatic patients, the defective airway epithelial barrier allows the stimulus to pass through the airway tissues ${ }^{26}$ which triggers an immune response, leading to narrowing of the airway and hypersecretion of airway mucus. ${ }^{26} \mathrm{NF}-\mathrm{\kappa B}$ and caspase-1 signalling pathways play an 
essential role in the pathophysiology of asthma. ${ }^{27-31}$ Both pathways involve in thymic stromal lymphopoietin (TSLP) production, which is highly related to the pathogenesis of atopic asthma and other allergic diseases. ${ }^{27,28,32-37}$ TSLP is a pro-allergic cytokine that acts on a variety of cells during inflammatory events, including eosinophils, basophils, dendritic cells, mast cells, B cells, innate type II cells, CD4(+) T cells, CD8(+) T cells, natural killer T cells, as well as, epithelial cells. $^{38-40}$ Other than regulating the production of TSLP, NF- $\kappa$ B signalling pathway also regulates the production of inflammatory cytokines and immunoglobulins in asthma. ${ }^{29-31}$ Activation of NF- $\mathrm{BB}$ signaling pathways can increase the production of inflammatory cytokines such as IL-1 $\beta$, IL-2, IL-4, IL-5, IL-6, IL-13, and IL-17.41 Increased production of IL-2, IL-5 and IL-13 from T-helper (Th)2 cells will subsequently increase the production of B-lymphocyte $\operatorname{IgE}$, leading to asthmatic reactions. ${ }^{41,42}$ Moreover, prolonged eosinophil inflammation during asthma

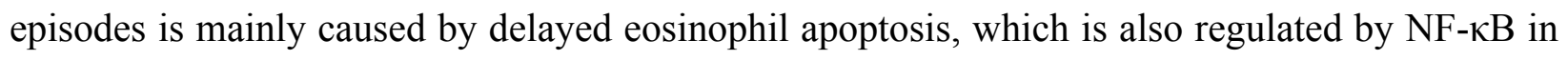
the body. ${ }^{43-45}$ In other words, NF- $\kappa$ B pathway also plays a vital role in the infiltration and function of the inflammatory cells. To conclude with all the existing findings, the suppression of NF- $\kappa \mathrm{B}$ and caspase-1 signalling pathways might be an alternative approach in the therapeutic intervention of asthma medication.

\subsection{Pulmonary fibrosis}

Pulmonary fibrosis is a chronic pulmonary disease which is often caused by dysregulated healing of a lung injury. ${ }^{46,47}$ Pulmonary fibrosis is characterized by worsening lung functions along with respiratory failure. This condition is associated with high mortality and economic burden. ${ }^{46-48}$ Idiopathic pulmonary fibrosis (IPF), which is caused by unknown factors, is the

most common type of pulmonary fibrosis diagnosed worldwide. ${ }^{46-48}$ Although, there are no comprehensive systematic reviews on IPF to date, the incidences of IPF in North America and 
Europe were in the range of 3-9 per 100,000 cases each year, according to the data compiled by Hutchinson et al. ${ }^{49}$ Pulmonary fibrosis is considered as a rare disease, but the incidence rates and severity have increased over the years. ${ }^{50}$ In normal conditions, the lungs when injured by noxious agents will go through different phases of wound healing, namely, injury, inflammation, and repair. Following the wound-healing processes, the damage of the injured organ will be minimized, and the architecture of the lung tissue will be restored to reacquire normal function. ${ }^{46,47}$ However, repetitive stimulation and injury of the lung tissue with noxious agents such as toxic chemical, allergens, radiation or other unknown factors may result in the dysregulation of the tissue repair responses, triggering a persistent inflammatory response. ${ }^{46-48}$ The extensive and recurring inflammation will then progressively evolve into pathogenic fibrotic response, causing fibrosis in the lungs and eventually impair the exchange of gases in the system. $^{46-48}$

Pulmonary fibrosis is normally associated with significant histological changes in lung architecture, mostly caused by extensive mesenchymal cell proliferation, that eventually lead to excessive collagen deposition. ${ }^{51}$ High levels of hydroxyproline often reflects the accumulation of collagen in the lung tissues. ${ }^{52,53}$ In addition to that, mast cell proliferation also contributes a essential role in the pathogenesis of pulmonary fibrosis. During the inflammatory response, degranulated mast cells release histamine, which increases the secretion of fibrogenic cytokines via the upregulation of fibroblast activation..$^{54,55}$

Similar to other chronic respiratory diseases, NF- $\mathrm{kB}$ signalling pathway is also involved in the pathophysiology of pulmonary fibrosis. Activation of NF-kB pathway is associated with elevation in the levels of nitric oxide synthase (iNOS), TGF- $\beta 1$, and TNF- $\alpha .{ }^{54}$ Enhanced activation of iNOS increases the production of nitric oxide (NO) in the body, resulting in severe 
oxidative stress. Free radical peroxidation products produced under increased oxidative stress, causes the destruction of cell membrane and eventually leads to pulmonary fibrosis. ${ }^{56,57}$ On the other hand, increased levels of multi-function cytokines, namely, TGF- $\beta 1$ are highly associated to the pathogenesis of pulmonary fibrosis, as they stimulate the growth of myofibroblasts and fibroblasts, promoting the synthesis and deposition of extracellular matrix (ECM) and suppress the degradation of collagen while promoting its deposition and synthesis in the lung tissue. ${ }^{54,58,59}$

Moreover, pulmonary fibrosis is also associated with oxidative tissue damage, which is often indicated by increased activity of malondialdehyde (MDA), hydroperoxides (OH) and nitrite (NO). ${ }^{54,60,61}$ The redox sensing transcription factor, nuclear factor E2-related factor 2 (Nrf2) also plays a vital role in maintaining the balance between the activity of oxidants and antioxidants in the cells. ${ }^{54}$ Dysregulated Nrf2 is often one of the factors that is associated with aggravating pulmonary fibrosis. In addition, inflammatory cell infiltration often contributes an essential role in the pathophysiology of pulmonary fibrosis, and the level of myeloperoxidase (MPO) can be used to indicate the degree of neutrophilic accumulation in the body tissue. ${ }^{62}$

To date, the only cure available for IPF is lung transplantation and the most recent first line antifibrotic agents approved by the FDA (pirfenidone and nintedanib) can only stabilize and delay the disease progression in IPF, without providing absolute cure from the disease. ${ }^{48,63}$ Therefore, further efforts are needed to discover advanced and potent pharmacotherapy for pulmonary fibrosis.

\subsection{Lung Cancer}

Lung cancer is another respiratory disease that involves the inflammatory response and has the highest mortality rate worldwide. ${ }^{64}$ Based on the Global Cancer Statistics 2018, lung 
cancer has the highest incidence rate, contributing to $11.6 \%$ of all cancer diagnosis. Lung cancer, being the leading cause of cancer deaths, comprises of $18.4 \%$ of cancer deaths in total with an estimation of over 1.8 million deaths over a year. ${ }^{64}$ Lung cancer can be categorised into two major types; non-small cell lung cancer (NSCLC) and small cell lung cancer (SCLC). The diagnosis rate of NSCLC (85\%) is comparably higher than SCLC (15\%), with a ratio of approximately 5:1. ${ }^{65,66} \mathrm{SCLC}$ first appears in the bronchi, which is located in the center of the chest. NSCLC on the other hand, can be further categorized into three sub-classifications, namely adenocarcinoma (40\%), squamous-cell carcinoma (30\%) and large-cell lung cancer (10\%). In particular, squamous-cell carcinoma is most closely linked with cigarette smoking. ${ }^{65}$ According to Hanahan et al., the main indications of cancer, in general, include uncontrollable cell proliferation, eluding of growth factors, angiogenesis, invasions of hyper-proliferating cells and metastasis. ${ }^{67}$ Inflammatory molecules play a crucial role in the development of lung cancer involving several events that may affect the malignancy of tumours. Gomes et al., reported that inflammatory cells function as tumour promoters that are responsible in the formation of malignant tumours from initiated cells. The dysregulation of cell growth results in the production of inflammatory molecules, including chemokines and cytokines that facilitate the development of cancer. TNF- $\alpha, \mathrm{NF}-\mathrm{\kappa B}$ and TGF- $\beta$ are a few of the cytokines that contribute towards the development of cancer. ${ }^{66} \mathrm{P} 38$ mitogen activated protein kinase (p38/MAPK), particularly p38 has been reported to suppress cell proliferation. Nonetheless, in lung cancer, the activated p38 is downregulated, and hence, initiates cell growth. ${ }^{68}$ Moreover, signal transducer and activator of transcription 3 (STAT3) is a transcription factor that plays a significant role in the pathogenesis of lung cancer. The activation of STAT3 not only promotes cell proliferation, but also initiates survival of tumour cells. ${ }^{69}$ The treatment of SCLC is divided in to two stages, namely limited 
stage (LS) and extensive stage (ES). In the study conducted by Kalemkerian et al., the standard treatment of LS-SCLC is chemotherapy with carboplatin or cisplatin, with the addition of etoposide for approximately 4 to 6 cycles, together with early, concurrent thoracic radiotherapy (RT). As for patients with stage 1 LS-SCLC, the treatment option is surgical excision followed by adjuvant chemotherapy. Patients with ES-SCLC on the other hand, can be treated with platinum-based chemotherapy of two drugs such as cisplatin and etoposide for 4 to 6 cycles, followed by prophylactic cranial irradiation (PCI) if patients respond well to initial chemotherapy. ${ }^{70-72}$ Furthermore, stage I, II and IIIA NSCLC patients can be treated with surgical resection, whereas, patients with stage IIA, IIB and IIIA NSCLC normally receive chemotherapy following surgery to ensure all remaining cancer cells are killed. Nonetheless, radiotherapy is the alternative treatment for patients who are not suitable for surgery and do not respond to chemotherapy. ${ }^{73}$

\section{The role of berberine in respiratory inflammatory diseases}

\subsection{Berberine and COPD}

HwangRyunHaeDok-Tang (HRHD), an Eastern herbal formula, used not only in China, but also in Korea and Japan to treat inflammatory diseases, contains 4 major constituents. ${ }^{85}$ One of the main components of HRHD is Coptidis rhizoma, which contains the anti-inflammatory substance, berberine. ${ }^{13,85}$ A study conducted by Shin et al., reported a decrease in neutrophil counts in the broncho-alveolar lavage fluid (BALF) in HRHD treated animals. The rats were administered with either $100 \mathrm{mg} / \mathrm{kg}$ or $200 \mathrm{mg} / \mathrm{kg}$ of the formulation. Moreover, HRHD-treated organisms are found to have reduced levels of TNF- $\alpha$, IL-1B and IL-6. HRHD is also found to inhibit NF- $\kappa \mathrm{B}$ activation, eventually decreasing its activity, which then results in the suppression

of inflammatory responses caused by both CS and LPS exposures. The increased expression and 
activity of MMPs are also suppressed in HRHD-administered animals. ${ }^{13}$ Another study conducted by Lin et al., reported that berberine, at a dose of $50 \mathrm{mg} / \mathrm{kg}$, when administered intragastrically, significantly caused a decline in the number of neutrophils and total cells in BALF. Myeloperoxidase (MPO) activity that indicates the neutrophil accumulation in the lungs, caused by CS exposure, is also reduced in berberine-administered mice. Decrease in proinflammatory cytokine (TNF- $\alpha$ and IL-6) levels is also noticed in berberine-treated mice. Besides, berberine also causes a crucial decrease in NF- $\mathrm{KB}$ nuclear translocation and its DNA activity. ${ }^{86} \mathrm{Li}$ et al., reported that berberine pre-treatment at $1.25 \mu \mathrm{M}$ concentration decreases the mRNA expression of iNOS. Cell lines treated with berberine demonstrated a suppressive effect on the levels of pro-inflammatory cytokines (TNF- $\alpha$, IL-1 $\beta$ and IL-6). In in vivo studies, berberine at a dose of $20 \mathrm{mg} / \mathrm{kg}$ demonstrated a significant reduction in inflammation in mice.

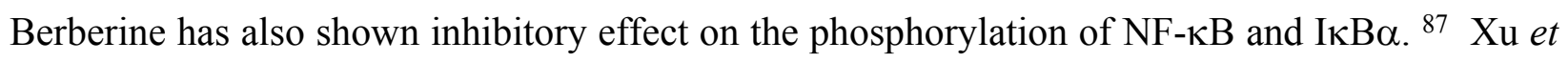
al., also reported in their study that berberine reduces the accumulation of total cells in BALF, at the same time, suppresses the entry of neutrophils into BALF. Levels of inflammatory mediators (TNF- $\alpha$, IL-1 $\beta$ and MCP-1) were found to be remarkably reduced in berberine-treated mice at doses of either $5 \mathrm{mg} / \mathrm{kg}$ or $10 \mathrm{mg} / \mathrm{kg}$. In addition, p38MAPK activity that portrays an important role in COPD is found to be attenuated in mice administered with berberine. ${ }^{88}$ Hence, the antiinflammatory properties of berberine presents a potential case in the treatment of COPD.

\subsection{Berberine and asthma}

High levels of TSLP expressions have been detected in asthmatic airways in human and animal models, and researchers suggest that suppression of TSLP will be a positive approach to modulate allergic inflammatory diseases including asthma. ${ }^{32-37}$ Berberine has shown to suppress TSLP expression effectively. Based on the studies carried out by Moon et al., (2011), decreased 
TSLP production and mRNA expression were observed in HMC-1 cells in berberine treatment group of different concentrations without showing cytotoxicity. ${ }^{36}$ The TSLP production was also reduced in primary mast cells under the treatment of berberine. The researchers concluded that the low TSLP production is highly associated to the downregulation of NF- $\mathrm{kB}$ and caspase-1 pathway in HMC-1 cells by berberine..$^{27,28}$ These results proved that TSLP production is governed by NF- $\mathrm{kB}$ and caspase-1 pathways, and inhibition of both these pathways can result in low TSLP production..$^{27,28}$ The study also suggested that berberine can modulate the inflammatory response associated with PMA plus A23187 via inhibiting the production of TSLP, and berberine can be one of the potential therapeutic interventions in treating asthma.

In addition to regulating the production of TSLP, berberine also has been shown to inhibit NF-kB signalling pathway and its subsequent inflammatory response effectively. Li et al., studied the anti-inflammatory effects of berberine on ovalbumin-induced asthma in experimental rats. ${ }^{41}$ The rats were administered either $100 \mathrm{mg} / \mathrm{kg}$ or $200 \mathrm{mg} / \mathrm{kg}$ of berberine. Based on the results, the signalling of NF-kB pathway was inhibited by berberine treatment. When compared to berberine treatment group, vehicle group and control group, similar expression of IкB $\alpha$

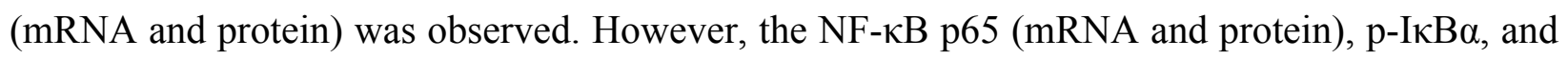
p-NF-kB p65 expression were found to be markedly lower in berberine treated group. The groups treated with berberine also showed lower NF- $\mathrm{kB}$ p65 DNA binding activity compared to the vehicle group. It also significantly reduced the levels of inflammatory cytokines (IL-1 $\beta$, IL-4, IL-5, IL-6, IL-13, and IL-17) and OVA-specific IgE in BALF in contrast with the vehicle group in a dose-dependent pattern. It is hypothesized that NF- $\mathrm{kB}$ pathway regulates the production of inflammatory cytokines, and suppression of this pathway by berberine decreases the level of inflammatory cytokines. ${ }^{41}$ Suppression of NF- $\mathrm{kB}$ pathway also indirectly decreases the 
production of B-lymphocyte IgE due to low production of cytokines such as IL-2, IL-5 and IL-13 by Th2 cells. ${ }^{41,42}$ Besides, the inflammatory scores of the treatment groups (both low-dose and high-dose group) were markedly decreased compared to vehicle group, suggesting that berberine was able to decrease the infiltration of the inflammatory cells in asthmatic lung tissue. These results suggested that the NF- $\mathrm{KB}$ pathway inhibition by berberine can induce eosinophil apoptosis, thus reducing the inflammatory response. ${ }^{44,45}$ In addition, the amount of the inflammatory cells (neutrophil, eosinophils, lymphocytes, and macrophages) present in BALF of the group treated with berberine were markedly reduced compared to the vehicle group treated only with PBS $(\mathrm{P}<0.05)$. Overall, berberine was effective in suppressing the inflammatory response of ovalbumin-induced asthma in rat model with a dose-dependent manner via inhibition of the over-reactive NF- $\mathrm{kB}$ signalling pathway.

\subsection{Effect of berberine on pulmonary fibrosis}

Pulmonary fibrosis is normally associated with significant histological changes in the lung architecture following pathogenic fibrotic response. ${ }^{51}$ Based on the study carried out by Chitra et al., berberine reduces the histological changes mediated by bleomycin in the lung tissue of rat models. ${ }^{54}$ The Ashcroft quantitative pathological scoring of berberine treatment group was significantly lower than the bleomycin-induced rat model. ${ }^{54}$ Berberine also reduced the level of hydroxyproline, the recruitment of mast cell and histamine release in bleomycin-induced rat

model. ${ }^{54}$ These results suggest that berberine significantly reduces the accumulation and deposition of collagen, thus slowing the histological alterations in pulmonary fibrosis.

In addition to that, studies have also reported that suppression of NF- $\mathrm{BB}$ signalling pathway may alleviate the progress of pulmonary fibrosis. ${ }^{54,58,59}$ According to the study carried out by Chitra et al., the activation of NF- $\mathrm{kB}$ signalling pathway was significantly downregulated 
in the berberine treatment group compared to the bleomycin induced animal groups, suggesting that berberine is effective in suppressing NF- $\mathrm{BB}$ signalling pathway. ${ }^{54}$ The treatment group also showed significantly lower expression of iNOS, TGF- $\beta 1$ and TNF- $\alpha$, which most likely resulted from the downregulating NF- $\mathrm{kB}$ activation. The studies revealed that berberine inhibits TGF- $\beta 1$ via the activation of Smad 7 and inhibition of Smad 2/3 activation. ${ }^{89}$ In addition, the study by Javad-Mousavi et al., also revealed that the treatment groups that received an oral dose of either $100 \mathrm{mg} / \mathrm{kg}, 200 \mathrm{mg} / \mathrm{kg}$ or $400 \mathrm{mg} / \mathrm{kg}$ of the Berberis vulgaris fruit extract have significantly lower TGF- $\beta 1$ and TNF- $\alpha$ compared to the group which was exposed only to paraquat. ${ }^{90}$

Studies also showed that berberine can increase the levels of antioxidants in the body, consequently decreasing the oxidative stress. Based on previous studies, the induction of Nrf2 expression with antioxidants may be a therapeutic intervention to suppress the progression of pulmonary fibrosis. ${ }^{54,91}$ The study carried out by Chitra et al., prove that berberine treatment can reduce the levels of MDA, $\mathrm{OH}$ and $\mathrm{NO}$ in both BALF and lung tissue compared to bleomycininduced rat model. ${ }^{54}$ Besides that, the Nrf2 expression was also significantly higher in the berberine treated group, suggesting that the upregulation of the antioxidant levels was through the activation of $\mathrm{Nrf} 2$ expression. ${ }^{54}$ Comparatively, berberine treatment group showed more efficacy in reducing oxidative stress at the preventive phase (0-14 days) compared to therapeutic phase (14-28 days), and this may be due to the nature of berberine that scavenge free radical produced, which inhibits the free radical chain reaction in the initial phase. ${ }^{54}$

Other than that, several studies have also suggested that berberine has the ability to reduce the levels of other inflammatory mediators. Based on the study carried out by Chitra et al., the level of MPO was increased in the bleomycin-induced control group and berberine treatment significantly reduce the level of MPO in both therapeutic and preventive aspects. ${ }^{54}$ 
This suggested that berberine can reduce neutrophil accumulation in the bleomycin-induced lung tissue. Besides, based on the study carried out by Javad-Mousavi et al., berberine treatment group also showed reduced pleiotropic cytokine, interleukin (IL)-6, which is involved in inflammation, haematopoiesis, and immune responses..$^{90,92}$ The study carried out by Guan et al., showed that berberine can increase the mRNA expression of human growth factor (HGF) and phosphatase and tensin homolog (PTEN) in the colon after oral administration..$^{93}$ However, the study shows that upregulation of HGF secretion is the key mechanism for the anti-fibrotic effect of berberine, where the increased HGF secretion is highly associated with the PPAR- $\gamma$ activation by berberine. ${ }^{93}$

\subsection{Effect of berberine in lung cancer}

A study conducted by Fang Zheng et al., reported that berberine reduces the cell viability of NSCLC cells (A549). Berberine disrupts the events in the $\mathrm{G}_{0} / \mathrm{G}_{1}$ phase of cell cycle in which the proportions of cells in the particular phase is found to be increased, indicating the initiation of cell cycle arrest in that phase. Furthermore, the presence of marked granular apoptotic bodies as well as increased rate of apoptosis are observed in berberine-treated cell lines. These conditions signify the ability of berberine to initiate apoptosis of NSCLC cells. ${ }^{94}$ Extracellular single-regulated kinase1/2 (ERK1/2) and p38 mitogen activated protein kinase (p38/MAPK) are both involved in cell apoptosis. Berberine, as shown in the study, increases the activation of both ERK1/2 and p38/MAPK, eventually increasing cell apoptosis. ${ }^{94,95}$ Forkhead homeobox type O3a (FOXO3a) is a tumour suppressor that is activated to upregulate the expression of proteins involved in cell cycle arrest and apoptosis. ${ }^{94,96}$ Berberine plays its role in suppressing tumour by increasing the activity of FOXO3a. ${ }^{94}$ 
In a study investigated by Santosh et al., it is proved that berberine causes a decrease in cell viability of NSCLC cells, eventually resulting in the inhibition of proliferation of NSCLC cells. Bax and Bak are examples of pro-apoptotic proteins, whereas, BcI-2 and BcI-x1 are antiapoptotic proteins. Berberine causes overexpression of pro-apoptotic proteins and underexpression of anti-apoptotic proteins. The regulation mechanisms of these proteins by berberine contribute to the apoptosis of NSCLC cells. Additionally, the cancer cells become more susceptible to the berberine-induced apoptosis due to the increased ratio of Bax:BcI-2 by berberine. Moreover, berberine is shown to disrupt the mitochondrial membrane potential. The disruption of the membrane potential of mitochondria plays a crucial role in the initiation of cell apoptosis. This condition is indicated by the liberation of Cytochrome $\mathrm{C}$ and Smac/DIABLO into the cytosol, which activate caspase-3, initiating cell death. Berberine is also found to directly increase the levels of Cytochrome $\mathrm{C}$ and Smac/DIABLO in the cytosol. Other than that, the fluorescence emission of JC-1 dye turns from red to green, signifying that the mitochondrial membrane potential has been disrupted. In berberine treated cell lines, the number of cells that displays green fluorescence is elevated, indicating the increased disruption of membrane potential of mitochondria by berberine. ${ }^{97}$ Hence, this shows the role of berberine in promoting cell apoptosis by interrupting the function of mitochondria of the cells.

Another study carried out by Zhu et al., showed the anti-cancer effect of berberine. Cells in the S phase of the cell cycle are represented by EdU-positive cells. Berberine significantly decreased the number of EdU-positive cells. This again shows that berberine is able to inhibit cell proliferation in lung cancer. Besides, berberine is also found to induce early and late cell apoptosis. Tumour spheroids that consist of cancer stem-cells imitate in-vivo tumour. Berberine is observed to not only reduce the number and size of the tumour spheroids, but also to inhibit 
the formation of these spheroids, indicating its ability to subside the formation of in-vivo tumours, such as NSCLC cells. ${ }^{98}$ In lung cancer, STAT3 is activated. Berberine, nonetheless, suppresses the activated form of STAT3 which causes the inhibition of cell growth and initiation of apoptosis. ${ }^{98,99}$

\section{Future perspectives and conclusion}

Preliminary studies have proven the anti-inflammatory effect of berberine in respiratory inflammatory diseases, that include COPD, asthma, pulmonary fibrosis and lung cancer. Based on the studies, berberine has been proven to activate the ERK1/2 \& p38 MAPK, caspase-3 and FOXO3a pathways while inhibiting the activation of NF- $\kappa \mathrm{B}$ and caspase- 1 signalling pathways. Several studies have shown that berberine treatment group reduces the level of inflammatory cytokines (TNF- $\alpha$, IL-6, IL-1B, MDA, OH and NO) as well as the inflammatory cell infiltration and collagen deposition. Berberine also decreased the activity of MPO and p38/MAPK, while reducing the mRNA expression of iNOS, TSLP and PTEN. The anti-apoptotic protein, BcI-2 \& BcI-x1 are downregulated in berberine treatment group whereas the pro-apoptotic proteins (Bax \& Bak) and Nrf2 expression were upregulated. These findings suggest the therapeutic potential of berberine in respiratory inflammatory diseases. However, there are several limitations with regard to the therapeutic applications of berberine. Firstly, there are not many clinical studies on berberine and secondly, the safety profile and toxicity of berberine are still not well-known due to limited number of studies, both preliminary and clinical. Berberine exerts its cytotoxic effect only on lung cancer cells but not on non-neoplastic cells such as human bronchial epithelial cells, suggesting that berberine may cause limited side effects on non-neoplastic cells. ${ }^{97}$ Thus, future studies are needed to further investigate the safety profile and toxicity of berberine, targeting inflammatory diseases in the respiratory system. 


\section{Conflict of interest}

The authors declared no conflict of interest.

\section{Acknowledgement}

The authors would like to thank International Medical University (IMU), Malaysia for providing the financial support for the project. Also, thanks to the Hunter Medical Research Institute (HMRI), The University of Newcastle, NSW 2308, Australia and the Discipline of Pharmacy,

Graduate School of Health, University of TechnologySydney, NSW 2007, Australia for providing necessary support.

\section{References}

1. Chen L, Deng H, Cui H, Fang J, Zuo Z, Deng J, et al. Inflammatory responses and inflammation-associated diseases in organs. Oncotarget. 2018 Jan;9(6):7204-18.

2. Libby P. Inflammatory Mechanisms: The Molecular Basis of Inflammation and Disease. Nutr Rev. 2008 Jun;65(suppl_3):S140-6.

3. Zhou Y, Hong Y, Huang H. Triptolide Attenuates Inflammatory Response in Membranous Glomerulo-Nephritis Rat via Downregulation of NF-\&amp;\#x03BA;B Signaling Pathway. Kidney Blood Press Res. 2016;41(6):901-10.

4. Moldoveanu B, Otmishi P, Jani P, Walker J, Sarmiento X, Guardiola J, et al. Inflammatory mechanisms in the lung. J Inflamm Res. 2009;2:1-11.

5. Leitch AE, Duffin R, Haslett C, Rossi AG. Relevance of granulocyte apoptosis to resolution of inflammation at the respiratory mucosa. Mucosal Immunol. 2008 
Sep;1(5):350-63.

6. Brusselle G, Bracke K. Targeting Immune Pathways for Therapy in Asthma and Chronic Obstructive Pulmonary Disease. Ann Am Thorac Soc. 2014 Dec;11(Supplement 5):S3228.

7. Wong J, Magun B, Wood L. Lung inflammation caused by inhaled toxicants: a review. Int J Chron Obstruct Pulmon Dis. 2016 Jun;1391.

8. Barnes PJ, Burney PGJ, Silverman EK, Celli BR, Vestbo J, Wedzicha JA, et al. Chronic obstructive pulmonary disease. Nat Rev Dis Prim [Internet]. 2015 Dec 3 [cited 2019 Aug 27];1(1):15076. Available from: http://www.nature.com/articles/nrdp201576

9. Barnes PJ. Inflammatory mechanisms in patients with chronic obstructive pulmonary disease. Vol. 138, Journal of Allergy and Clinical Immunology. Mosby Inc.; 2016. p. 1627.

10. Rabe KF, Watz H. Chronic obstructive pulmonary disease. Lancet [Internet]. 2017 May [cited 2019 Aug 27];389(10082):1931-40. Available from: https://inkinghub.elsevier.com/retrieve/pii/S0140673617312229

11. Evaluation I for HM and. Findings from the Global Burden of Disease Study 2017. Lancet. 2018;

12. American Thoracic Society PATIENT EDUCATION | INFORMATION SERIES www.thoracic.org CLIP AND COPY [Internet]. 2019. Available from: https://perf2ndwind.org/

13. Shin NR, Ko JW, Park SH, Cho YK, Oh SR, Ahn KS, et al. Protective effect of 
HwangRyunHaeDok-Tang water extract against chronic obstructive pulmonary disease induced by cigarette smoke and lipopolysaccharide in a mouse model. J Ethnopharmacol. 2017 Mar 22;200:60-5.

14. Shin IS, Park JW, Shin NR, Jeon CM, Kwon OK, Kim JS, et al. Melatonin reduces airway inflammation in ovalbumin-induced asthma. Immunobiology. 2014 Dec 1;219(12):901-8.

15. Cassini-Vieira P, Araújo FA, Da Costa Dias FL, Russo RC, Andrade SP, Teixeira MM, et al. INOS Activity Modulates Inflammation, Angiogenesis, and Tissue Fibrosis in Polyether-Polyurethane Synthetic Implants. Mediators Inflamm. 2015;2015.

16. Choudhury MG, Saha N. Induction of inducible nitric oxide synthase by lipopolysaccharide and the influences of cell volume changes, stress hormones and oxidative stress on nitric oxide efflux from the perfused liver of air-breathing catfish, Heteropneustes fossilis. PLoS One. 2016 Mar 1;11(3).

17. Snitker S, Xie K, Ryan KA, Yu D, Shuldiner AR, Mitchell BD, et al. Correlation of Circulating MMP-9 with White Blood Cell Count in Humans: Effect of Smoking. PLoS One. 2013 Jun 25;8(6).

18. Qaseem A, Wilt TJ, Weinberger SE, Hanania NA, Criner G, Molen T van der, et al. Diagnosis and Management of Stable Chronic Obstructive Pulmonary Disease: A Clinical Practice Guideline Update from the American College of Physicians, American College of Chest Physicians, American Thoracic Society, and European Respiratory Society. Ann Intern Med [Internet]. 2011 Aug 2 [cited 2019 Aug 27];155(3):179. Available from: http://annals.org/article.aspx?doi=10.7326/0003-4819-155-3-201108020-00008

19. PAUWELS RA, BUIST AS, CALVERLEY PMA, JENKINS CR, HURD SS. Global 
Strategy for the Diagnosis, Management, and Prevention of Chronic Obstructive Pulmonary Disease. Am J Respir Crit Care Med [Internet]. 2001 Apr 14 [cited 2019 Aug 27];163(5):1256-76. Available from: http://www.atsjournals.org/doi/abs/10.1164/ajrccm.163.5.2101039

20. Lahousse L, Verhamme KM, Stricker BH, Brusselle GG. Cardiac effects of current treatments of chronic obstructive pulmonary disease. The Lancet Respiratory Medicine. 2016.

21. Kudo M, Ishigatsubo Y, Aoki I. Pathology of asthma. Front Microbiol. 2013 Sep;4:263.

22. Kudo M, Ishigatsubo Y, Aoki I. Pathology of asthma. Front Microbiol [Internet]. 2013 Sep 10 [cited 2019 Aug 27];4:263. Available from: http://www.ncbi.nlm.nih.gov/pubmed/24032029

23. GBD 2015 Chronic Respiratory Disease Collaborators JB, Abajobir AA, Abate KH, Abera SF, Agrawal A, Ahmed MB, et al. Global, regional, and national deaths, prevalence, disability-adjusted life years, and years lived with disability for chronic obstructive pulmonary disease and asthma, 1990-2015: a systematic analysis for the Global Burden of Disease Study 2015. Lancet Respir Med. 2017 Sep;5(9):691-706.

24. Froidure A, Mouthuy J, Durham SR, Chanez P, Sibille Y, Pilette C. Asthma phenotypes and IgE responses. Eur Respir J [Internet]. 2016 Jan [cited 2019 Sep 24];47(1):304-19. Available from: http://www.ncbi.nlm.nih.gov/pubmed/26677936

25. Barnes PJ. Inhaled Corticosteroids. Pharmaceuticals (Basel) [Internet]. 2010 Mar 8 [cited 2019 Aug 27];3(3):514-40. Available from: http://www.ncbi.nlm.nih.gov/pubmed/27713266 
26. Xiao C, Puddicombe SM, Field S, Haywood J, Broughton-Head V, Puxeddu I, et al. Defective epithelial barrier function in asthma. J Allergy Clin Immunol [Internet]. 2011 Sep [cited 2019 Aug 27];128(3):549-556.e12. Available from: http://www.ncbi.nlm.nih.gov/pubmed/21752437

27. Moon P-D, Kim H-M. Thymic stromal lymphopoietin is expressed and produced by caspase-1/NF-kB pathway in mast cells. Cytokine [Internet]. 2011 Jun [cited 2019 Aug 29];54(3):239-43. Available from: http://www.ncbi.nlm.nih.gov/pubmed/21463955

28. Jeong H-J, Nam S-Y, Oh H-A, Han N-R, Kim Y-S, Moon P-D, et al. Interleukin-32induced thymic stromal lymphopoietin plays a critical role in macrophage differentiation through the activation of caspase-1 in vitro. Arthritis Res Ther [Internet]. 2012 Nov 28 [cited 2019 Aug 29];14(6):R259. Available from: http://arthritisresearch.biomedcentral.com/articles/10.1186/ar4104

29. Das J, Chen CH, Yang L, Cohn L, Ray P, Ray A. A critical role for NF-kappa B in GATA3 expression and TH2 differentiation in allergic airway inflammation. Nat Immunol [Internet]. 2001 Jan [cited 2019 Aug 29];2(1):45-50. Available from: http://www.ncbi.nlm.nih.gov/pubmed/11135577

30. Min HK, Kim S-M, Baek S-Y, Woo J-W, Park J-S, Cho M-L, et al. Anthocyanin Extracted from Black Soybean Seed Coats Prevents Autoimmune Arthritis by Suppressing the Development of Th17 Cells and Synthesis of Proinflammatory Cytokines by Such Cells, via Inhibition of NF-kB. Brand DD, editor. PLoS One [Internet]. 2015 Nov 6 [cited 2019 Aug 29];10(11):e0138201. Available from: http://www.ncbi.nlm.nih.gov/pubmed/26544846 
31. Zhang $\mathrm{T}$, Yang $\mathrm{S}, \mathrm{Du}$ J, Jinfu Y, Shumin W. Platycodin D Attenuates Airway Inflammation in a Mouse Model of Allergic Asthma by Regulation NF-kB Pathway. Inflammation [Internet]. 2015 Jun 13 [cited 2019 Aug 29];38(3):1221-8. Available from: http://www.ncbi.nlm.nih.gov/pubmed/25578175

32. Zhao J, Lee TH, Corrigan Kirsty Mallett C, Cousins D, Robinson D, Sun Ying G, et al. Chemokines and Disease Severity Correlates with Expression of Th2-Attracting Is Increased in Asthmatic Airways and Thymic Stromal Lymphopoietin Expression. 2017 [cited 2019 Aug 28]; Available from: http://www.jimmunol.org/content/174/12/8183

33. Han H, Xu W, Headley MB, Jessup HK, Lee KS, Omori M, et al. Thymic stromal lymphopoietin (TSLP)-mediated dermal inflammation aggravates experimental asthma. Mucosal Immunol [Internet]. 2012 May 22 [cited 2019 Aug 28];5(3):342-51. Available from: http://www.nature.com/articles/mi201214

34. He R, Geha RS. Thymic stromal lymphopoietin. Ann N Y Acad Sci [Internet]. 2010 Jan [cited 2019 Aug 28];1183(1):13-24. Available from: http://www.ncbi.nlm.nih.gov/pubmed/20146705

35. Rochman Y, Leonard WJ. Thymic stromal lymphopoietin: a new cytokine in asthma. Curr Opin Pharmacol [Internet]. 2008 Jun [cited 2019 Aug 28];8(3):249-54. Available from: http://www.ncbi.nlm.nih.gov/pubmed/18450510

36. Moon P-D, Choi I-H, Kim H-M. Berberine inhibits the production of thymic stromal lymphopoietin by the blockade of caspase- $1 / \mathrm{NF}-\mathrm{kB}$ pathway in mast cells. Int Immunopharmacol [Internet]. 2011 Nov [cited 2019 Aug 28];11(11):1954-9. Available from: http://www.ncbi.nlm.nih.gov/pubmed/21856447 
37. Shan L, Redhu NS, Saleh A, Halayko AJ, Chakir J, Gounni AS. Thymic stromal lymphopoietin receptor-mediated IL-6 and CC/CXC chemokines expression in human airway smooth muscle cells: role of MAPKs (ERK1/2, p38, and JNK) and STAT3 pathways. J Immunol [Internet]. 2010 Jun 15 [cited 2019 Aug 28];184(12):7134-43. Available from: http://www.ncbi.nlm.nih.gov/pubmed/20483734

38. Rochman Y, Leonard WJ. The Role of Thymic Stromal Lymphopoietin in CD8 ${ }^{+}$T Cell Homeostasis. J Immunol [Internet]. 2008 Dec 1 [cited 2019 Sep 24];181(11):7699-705. Available from: http://www.ncbi.nlm.nih.gov/pubmed/19017958

39. Redhu NS, Gounni AS. Function and mechanisms of TSLP/TSLPR complex in asthma and COPD. Clin Exp Allergy [Internet]. 2012 Jul [cited 2019 Sep 24];42(7):994-1005. Available from: http://www.ncbi.nlm.nih.gov/pubmed/22168549

40. Roan F, Bell BD, Stoklasek TA, Kitajima M, Han H, Ziegler SF. The multiple facets of thymic stromal lymphopoietin (TSLP) during allergic inflammation and beyond. J Leukoc Biol [Internet]. 2012 Jun [cited 2019 Sep 24];91(6):877-86. Available from: http://www.ncbi.nlm.nih.gov/pubmed/22442496

41. Li Z, Zheng J, Zhang N, Li C. Berberine improves airway inflammation and inhibits NF$\kappa \mathrm{B}$ signaling pathway in an ovalbumin-induced rat model of asthma. J Asthma [Internet]. 2016 Nov 25 [cited 2019 Aug 28];53(10):999-1005. Available from: http://www.ncbi.nlm.nih.gov/pubmed/27175622

42. Pelaia G, Vatrella A, Busceti MT, Gallelli L, Calabrese C, Terracciano R, et al. Cellular Mechanisms Underlying Eosinophilic and Neutrophilic Airway Inflammation in Asthma. Mediators Inflamm [Internet]. 2015 [cited 2019 Aug 29];2015:1-8. Available from: 
http://www.ncbi.nlm.nih.gov/pubmed/25878402

43. Kankaanranta H, Lindsay MA, Giembycz MA, Zhang X, Moilanen E, Barnes PJ. Delayed eosinophil apoptosis in asthma. J Allergy Clin Immunol [Internet]. 2000 Jul [cited 2019 Aug 29];106(1):77-83. Available from: http://www.ncbi.nlm.nih.gov/pubmed/10887309

44. Park YM, Bochner BS. Eosinophil Survival and Apoptosis in Health and Disease. Allergy, Asthma Immunol Res [Internet]. 2010 Apr [cited 2019 Aug 29];2(2):87. Available from: http://www.ncbi.nlm.nih.gov/pubmed/20358022

45. Fujihara S, Jaffray E, Farrow SN, Rossi AG, Haslett C, Hay RT. Inhibition of NF-kB by a cell permeable form of IкB $\alpha$ induces apoptosis in eosinophils. Biochem Biophys Res Commun [Internet]. 2005 Jan 21 [cited 2019 Aug 29];326(3):632-7. Available from: http://www.ncbi.nlm.nih.gov/pubmed/15596146

46. Wilson MS, Wynn TA. Pulmonary fibrosis: pathogenesis, etiology and regulation. Mucosal Immunol [Internet]. 2009 Mar [cited 2019 Aug 27];2(2):103-21. Available from: http://www.ncbi.nlm.nih.gov/pubmed/19129758

47. Barratt S, Creamer A, Hayton C, Chaudhuri N. Idiopathic Pulmonary Fibrosis (IPF): An Overview. J Clin Med [Internet]. 2018 Aug 6 [cited 2019 Aug 27];7(8):201. Available from: http://www.ncbi.nlm.nih.gov/pubmed/30082599

48. Sharif R. Overview of idiopathic pulmonary fibrosis (IPF) and evidence-based guidelines. Am J Manag Care [Internet]. 2017 Jul [cited 2019 Aug 27];23(11 Suppl):S176-82. Available from: http://www.ncbi.nlm.nih.gov/pubmed/28978212

49. Hutchinson J, Fogarty A, Hubbard R, McKeever T. Global incidence and mortality of 
idiopathic pulmonary fibrosis: a systematic review. Eur Respir J [Internet]. 2015 Sep 1 [cited 2019 Aug 28];46(3):795-806. Available from: http://www.ncbi.nlm.nih.gov/pubmed/25976683

50. Hutchinson J, Fogarty A, Hubbard R, McKeever T. Global incidence and mortality of idiopathic pulmonary fibrosis: a systematic review. Eur Respir J. 2015 Sep;46(3):795806.

51. Wolters PJ, Collard HR, Jones KD. Pathogenesis of idiopathic pulmonary fibrosis. Annu Rev Pathol [Internet]. 2014 [cited 2019 Sep 2];9:157-79. Available from: http://www.ncbi.nlm.nih.gov/pubmed/24050627

52. Kliment CR, Englert JM, Crum LP, Oury TD. A novel method for accurate collagen and biochemical assessment of pulmonary tissue utilizing one animal. Int J Clin Exp Pathol [Internet]. 2011 Apr [cited 2019 Sep 2];4(4):349-55. Available from: http://www.ncbi.nlm.nih.gov/pubmed/21577320

53. Todd NW, Luzina IG, Atamas SP. Molecular and cellular mechanisms of pulmonary fibrosis. Fibrogenesis Tissue Repair [Internet]. 2012 Jul 23 [cited 2019 Sep 2];5(1):11. Available from: http://www.ncbi.nlm.nih.gov/pubmed/22824096

54. Chitra P, Saiprasad G, Manikandan R, Sudhandiran G. Berberine attenuates bleomycin induced pulmonary toxicity and fibrosis via suppressing NF- $\mathrm{kB}$ dependant TGF- $\beta$ activation: A biphasic experimental study. Toxicol Lett [Internet]. 2013 May 23 [cited 2019 Aug 29];219(2):178-93. Available from: http://www.ncbi.nlm.nih.gov/pubmed/23523906

55. Pesci A, Bertorelli G, Gabrielli M, Olivieri D. Mast Cells in Fibrotic Lung Disorders. 
Chest [Internet]. 1993 Apr [cited 2019 Sep 2];103(4):989-96. Available from: http://www.ncbi.nlm.nih.gov/pubmed/8131513

56. Cantin AM, Hubbard RC, Crystal RG. Glutathione Deficiency in the Epithelial Lining Fluid of the Lower Respiratory Tract in Idiopathic Pulmonary Fibrosis. Am Rev Respir Dis [Internet]. 1989 Feb [cited 2019 Aug 31];139(2):370-2. Available from: http://www.ncbi.nlm.nih.gov/pubmed/2913886

57. Beeh KM, Beier J, Haas IC, Kornmann O, Micke P, Buhl R. Glutathione deficiency of the lower respiratory tract in patients with idiopathic pulmonary fibrosis. Eur Respir J [Internet]. 2002 Jun 1 [cited 2019 Aug 31];19(6):1119-23. Available from: http://www.ncbi.nlm.nih.gov/pubmed/12108866

58. Khalil N, Greenberg AH. The role of TGF-beta in pulmonary fibrosis. Ciba Found Symp [Internet]. 1991 [cited 2019 Sep 1];157:194-207; discussion 207-11. Available from: http://www.ncbi.nlm.nih.gov/pubmed/1712697

59. Li X, Li N, Ban C, Zhu M, Xiao B, Dai H. Idiopathic pulmonary fibrosis in relation to gene polymorphisms of transforming growth factor- $\beta 1$ and plasminogen activator inhibitor 1. Chin Med J (Engl) [Internet]. 2011 Jul 5 [cited 2019 Sep 1];124(13):1923-7. Available from: http://www.ncbi.nlm.nih.gov/pubmed/22088447

60. Giri SN, Biring I, Nguyen T, Wang Q, Hyde DM. Abrogation of bleomycin-induced lung fibrosis by nitric oxide synthase inhibitor, aminoguanidine in mice. Nitric Oxide [Internet]. 2002 Sep 1 [cited 2019 Sep 2];7(2):109-18. Available from: https://www.sciencedirect.com/science/article/pii/S1089860302001027?via\%3Dihub

61. Daniil ZD, Papageorgiou E, Koutsokera A, Kostikas K, Kiropoulos T, Papaioannou AI, et 
al. Serum levels of oxidative stress as a marker of disease severity in idiopathic pulmonary fibrosis. Pulm Pharmacol Ther [Internet]. 2008 Feb [cited 2019 Sep 2];21(1):26-31. Available from: https://linkinghub.elsevier.com/retrieve/pii/S1094553906001143

62. Fois AG, Paliogiannis P, Sotgia S, Mangoni AA, Zinellu E, Pirina P, et al. Evaluation of oxidative stress biomarkers in idiopathic pulmonary fibrosis and therapeutic applications: a systematic review. Respir Res [Internet]. 2018 [cited 2019 Sep 2];19(1):51. Available from: http://www.ncbi.nlm.nih.gov/pubmed/29587761

63. Sato S, Yanagihara T, Kolb MRJ. Therapeutic targets and early stage clinical trials for pulmonary fibrosis. Expert Opin Investig Drugs [Internet]. 2019 Jan 2 [cited 2019 Aug 27];28(1):19-28. Available from: https://www.tandfonline.com/doi/full/10.1080/13543784.2019.1554054

64. Bray F, Ferlay J, Soerjomataram I, Siegel RL, Torre LA, Jemal A. Global cancer statistics 2018: GLOBOCAN estimates of incidence and mortality worldwide for 36 cancers in 185 countries. CA Cancer J Clin. 2018;

65. Herbst RS, Heymach J V., Lippman SM. Molecular origins of cancer: Lung cancer. New England Journal of Medicine. 2008.

66. Gomes M, Teixeira AL, Coelho A, Araújo A, Medeiros R. The role of inflammation in lung cancer. Adv Exp Med Biol. 2014;

67. Hanahan D, Weinberg RA. Hallmarks of cancer: The next generation. Vol. 144, Cell. 2011. p. 646-74.

68. Fang Y, Wang J, Wang G, Zhou C, Wang P, Zhao S, et al. Inactivation of p38 MAPK 
contributes to stem cell-like properties of non-small cell lung cancer. Oncotarget. 2017;

69. Yin ZJ, Jin FG, Liu TG, Fu EQ, Xie YH, Sun RL. Overexpression of STAT3 potentiates growth, survival, and radioresistance of non-small-cell lung cancer (NSCLC) cells. J Surg Res. 2011;

70. Kalemkerian G. Small Cell Lung Cancer. Semin Respir Crit Care Med [Internet]. 2016 Oct 12 [cited 2019 Aug 28];37(05):783-96. Available from: http://www.thiemeconnect.de/DOI/DOI?10.1055/s-0036-1592116

71. Morabito A, Carillio G, Daniele G, Piccirillo MC, Montanino A, Costanzo R, et al. Treatment of small cell lung cancer. Crit Rev Oncol Hematol [Internet]. 2014 Sep [cited 2019 Aug 28];91(3):257-70. Available from: https://linkinghub.elsevier.com/retrieve/pii/S1040842814000523

72. Waqar SN, Morgensztern D. Treatment advances in small cell lung cancer (SCLC). Vol. 180, Pharmacology and Therapeutics. Elsevier Inc.; 2017. p. 16-23.

73. Zappa C, Mousa SA. Non-small cell lung cancer: Current treatment and future advances. Transl Lung Cancer Res. 2016 Jun 1;5(3):288-300.

74. Li F-S, Weng J-K. Demystifying traditional herbal medicine with modern approach. Nat Plants [Internet]. 2017 Aug 31 [cited 2019 Aug 21];3(8):17109. Available from: http://www.ncbi.nlm.nih.gov/pubmed/28758992

75. Abou El-Soud N. Herbal medicine in ancient Egypt. J Med plant Res [Internet]. 2010 [cited 2019 Aug 21];4(2):82-6. Available from: https://www.researchgate.net/publication/228634623_Herbal_medicine_in_ancient_Egypt 
76. Zhang Q, Cai L, Zhong G, Luo W. [Simultaneous determination of jatrorrhizine, palmatine, berberine, and obacunone in Phellodendri Amurensis Cortex by RP-HPLC]. Zhongguo Zhong Yao Za Zhi [Internet]. 2010 Aug [cited 2019 Aug 20];35(16):2061-4. Available from: http://www.ncbi.nlm.nih.gov/pubmed/21046728

77. Chander Junior Scientific Assistant V, Aswal J, Dobhal R, Uniyal D, Chander V. A review on Pharmacological potential of Berberine; an active component of Himalayan Berberis aristata [Internet]. Vol. 6, The Journal of Phytopharmacology. 2017 [cited 2019 Aug 20]. Available from: www.phytopharmajournal.com

78. Schor J. Clinical Applications for Berberine: Potential therapeutic applications in metabolic syndrome, type 2 diabetes, and dyslipidemia. Nat Med J [Internet]. 2012 [cited 2019 Aug 20];4(12). Available from: https://www.naturalmedicinejournal.com/print/587

79. Hu X, Zhang Y, Xue Y, Zhang Z, Wang J. Berberine is a potential therapeutic agent for metabolic syndrome via brown adipose tissue activation and metabolism regulation. Am J Transl Res [Internet]. 2018 [cited 2019 Aug 20];10(11):3322-9. Available from: http://www.ncbi.nlm.nih.gov/pubmed/30662589

80. Singh IP, Mahajan S. Berberine and its derivatives: a patent review $(2009-2012)$. Expert Opin Ther Pat [Internet]. 2013 Feb 12 [cited 2019 Aug 20];23(2):215-31. Available from: http://www.ncbi.nlm.nih.gov/pubmed/23231038

81. Tan H-L, Chan K-G, Pusparajah P, Duangjai A, Saokaew S, Mehmood Khan T, et al. Rhizoma Coptidis: A Potential Cardiovascular Protective Agent. Front Pharmacol [Internet]. 2016 Oct 7 [cited 2019 Aug 21];7:362. Available from: http://www.ncbi.nlm.nih.gov/pubmed/27774066 
82. Pang B, Yu X-T, Zhou Q, Zhao T-Y, Wang H, Gu C-J, et al. Effect of Rhizoma coptidis (Huang Lian) on Treating Diabetes Mellitus. Evidence-Based Complement Altern Med [Internet]. 2015 [cited 2019 Aug 21];2015:1-10. Available from: http://www.ncbi.nlm.nih.gov/pubmed/26508987

83. Yang S. The divine farmer's materia medica: a translation of the Shen Nong Ben Cao Jing [Internet]. 1st ed. Boulder CO: Blue Poppy Press; 1998 [cited 2019 Aug 20]. 198 p. Available from: https://www.worldcat.org/title/divine-farmers-materia-medica-atranslation-of-the-shen-nong-ben-cao-jing/oclc/41048949

84. Mazumder PM, Das S, Das S, Das MK. Phyto-pharmacology of Berberis aristata DC: a review. J Drug Deliv Ther [Internet]. 2011 Dec 10 [cited 2019 Aug 20];1(2). Available from: http://jddtonline.info/index.php/jddt/article/view/34

85. Kim SG, Poudel A, Kim YK, Jo HK, Jung HJ. Development of simultaneous analysis for marker constituents in Hwangryunhaedok-tang and its application in commercial herbal formulas. J Nat Med. 2013 Apr;67(2):390-8.

86. Lin K, Liu S, Shen Y, Li Q. Berberine attenuates cigarette smoke-induced acute lung inflammation. Inflammation. 2013 Oct;36(5):1079-86.

87. Li CL, Tan LH, Wang YF, Luo CD, Chen H Bin, Lu Q, et al. Comparison of antiinflammatory effects of berberine, and its natural oxidative and reduced derivatives from Rhizoma Coptidis in vitro and in vivo. Phytomedicine. 2019 Jan 1;52:272-83.

88. Xu D, Wan C, Wang T, Tian P, Li D, Wu Y, et al. Berberine attenuates cigarette smokeinduced airway inflammation and mucus hypersecretion in mice. Int J Clin Exp Med [Internet]. 2015 [cited 2019 Aug 29];8(6):8641-7. Available from: 
http://www.ncbi.nlm.nih.gov/pubmed/26309516

89. Chitra P, Saiprasad G, Manikandan R, Sudhandiran G. Berberine inhibits Smad and nonSmad signaling cascades and enhances autophagy against pulmonary fibrosis. J Mol Med [Internet]. 2015 Sep 17 [cited 2019 Aug 29];93(9):1015-31. Available from: http://www.ncbi.nlm.nih.gov/pubmed/25877860

90. Javad-Mousavi SA, Hemmati AA, Mehrzadi S, Hosseinzadeh A, Houshmand G, Rashidi Nooshabadi MR, et al. Protective effect of Berberis vulgaris fruit extract against Paraquatinduced pulmonary fibrosis in rats. Biomed Pharmacother [Internet]. 2016 Jul [cited 2019 Sep 1];81:329-36. Available from: http://www.ncbi.nlm.nih.gov/pubmed/27261610

91. Kang ES, Woo IS, Kim HJ, Eun SY, Paek KS, Kim HJ, et al. Up-regulation of aldose reductase expression mediated by phosphatidylinositol 3-kinase/Akt and Nrf2 is involved in the protective effect of curcumin against oxidative damage. Free Radic Biol Med [Internet]. 2007 Aug 15 [cited 2019 Sep 2];43(4):535-45. Available from: http://www.ncbi.nlm.nih.gov/pubmed/17640564

92. Tanaka T, Narazaki M, Kishimoto T. IL-6 in inflammation, immunity, and disease. Cold Spring Harb Perspect Biol [Internet]. 2014 Sep 4 [cited 2019 Sep 2];6(10):a016295. Available from: http://www.ncbi.nlm.nih.gov/pubmed/25190079

93. Guan C, Qiao S, Lv Q, Cao N, Wang K, Dai Y, et al. Orally administered berberine ameliorates bleomycin-induced pulmonary fibrosis in mice through promoting activation of PPAR- $\gamma$ and subsequent expression of HGF in colons. Toxicol Appl Pharmacol [Internet]. 2018 Mar 15 [cited 2019 Aug 29];343:1-15. Available from: http://www.ncbi.nlm.nih.gov/pubmed/29408570 
94. Zheng F, Tang Q, Wu J, Zhao S, Liang Z, Li L, et al. P38 $\alpha$ MAPK-mediated induction and interaction of FOXO3a and p53 contribute to the inhibited-growth and inducedapoptosis of human lung adenocarcinoma cells by berberine. J Exp Clin Cancer Res. 2014 Apr 26;33(1).

95. Khajah MA, Mathew PM, Luqmani YA. Inhibitors of PI3K/ERK1/2/p38 MAPK show preferential activity against endocrine-resistant breast cancer cells. Oncol Res. 2017;25(8):1283-95.

96. Liang Z, Wang X, Xu X, Xie B, Ji A, Meng S, et al. MicroRNA-608 inhibits proliferation of bladder cancer via AKT/FOXO3a signaling pathway. Mol Cancer. 2017 May 26;16(1).

97. Katiyar SK, Meeran SM, Katiyar N, Akhtar S. P53 cooperates berberine-induced growth inhibition and apoptosis of non-small cell human lung cancer cells in vitro and tumor xenograft growth in vivo. Mol Carcinog. 2009 Jan;48(1):24-37.

98. Zhu T, Li LL, Xiao GF, Luo QZ, Liu QZ, Yao KT, et al. Berberine Increases Doxorubicin Sensitivity by Suppressing STAT3 in Lung Cancer. Am J Chin Med. 2015 Oct $1 ; 43(7): 1487-502$.

99. Yin ZJ, Jin FG, Liu TG, Fu EQ, Xie YH, Sun RL. Overexpression of STAT3 potentiates growth, survival, and radioresistance of non-small-cell lung cancer (NSCLC) cells. J Surg Res. 2011 Dec;171(2):675-83. 


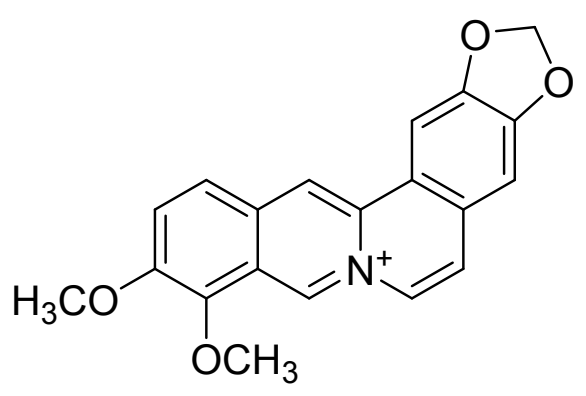

Figure 1: The chemical structure of berberine 


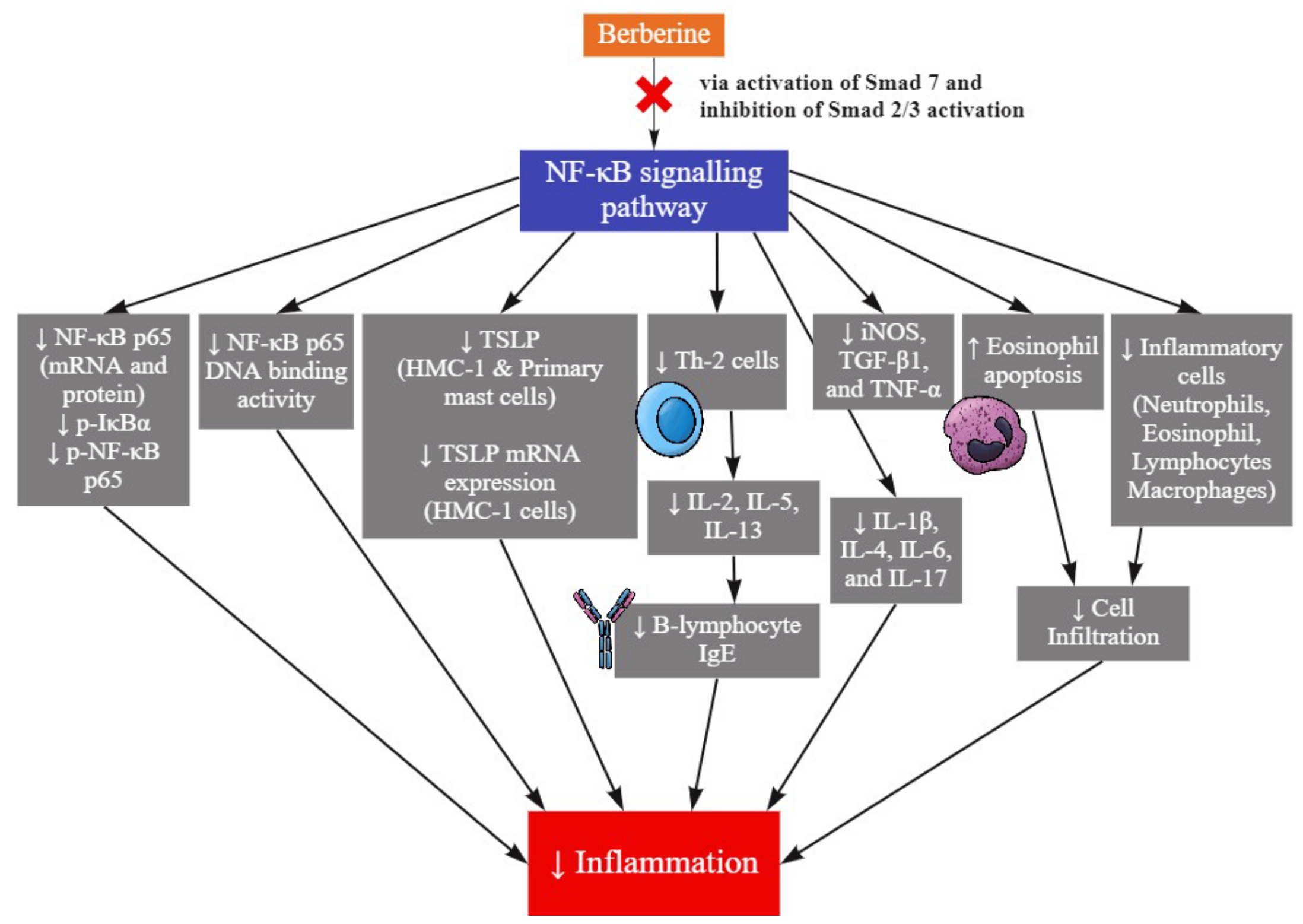

Figure 2: The effect of Berberine in NF- $\mathrm{KB}$ signaling pathway 

Table 1: The effect of berberine in various respiratory inflammatory diseases

\begin{tabular}{|c|c|c|c|}
\hline $\begin{array}{l}\text { Respiratory } \\
\text { diseases }\end{array}$ & $\begin{array}{l}\text { Pathway and } \\
\text { mediator } \\
\text { involved }\end{array}$ & Findings & References \\
\hline \multirow[t]{7}{*}{ COPD } & \multirow[t]{3}{*}{$\begin{array}{l}\text { NF- } \kappa \mathrm{B} \\
\text { signaling } \\
\text { pathway }\end{array}$} & $\begin{array}{l}\text { - Inhibited NF- } \kappa \mathrm{B} \text { activation } \\
\text { in berberine-treated animals } \\
\text { - Decreased activity of NF- } \\
\kappa \mathrm{B} \\
\text { - Reduced pro-inflammatory } \\
\text { cytokines (IL-1 } \beta \text {, IL-6 and } \\
\text { TNF- } \alpha \text { ) levels } \\
\text { - Suppressed inflammatory } \\
\text { response }\end{array}$ & $\begin{array}{l}\text { Shin et al. } \\
(2017) 13\end{array}$ \\
\hline & & 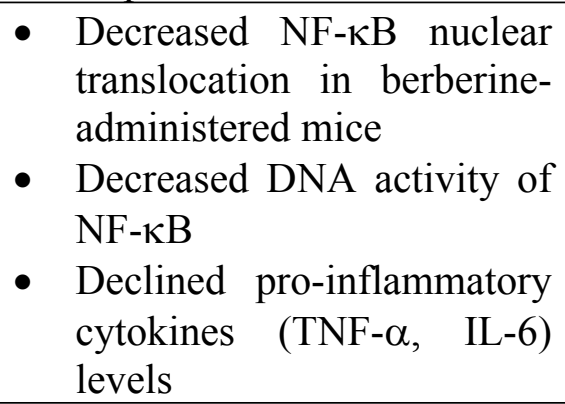 & $\operatorname{Lin}_{86}$ et al. (2013) \\
\hline & & $\begin{array}{l}\text { - Inhibited phosphorylation } \\
\text { of NF- } \kappa \mathrm{B} \text { in berberine- } \\
\text { treated cell lines } \\
\text { - Regression of pro- } \\
\text { inflammatory cytokines } \\
(\mathrm{TNF}-\alpha, \mathrm{IL}-1 \beta, \mathrm{IL}-6)\end{array}$ & $\begin{array}{l}\text { Li.C-L et al. } \\
(2019) 87\end{array}$ \\
\hline & MPO & $\begin{array}{l}\text { - } \begin{array}{l}\text { Reduced MPO activity in } \\
\text { berberine-treated mice }\end{array} \\
\text { - } \begin{array}{l}\text { Reduced number of } \\
\text { neutrophils in BALF }\end{array} \\
\end{array}$ & ${ }_{86}^{\text {Lin et al. (2013) }}$ \\
\hline & $\begin{array}{l}\text { Leucocyte } \\
\text { counts }\end{array}$ & $\begin{array}{l}\text { - Decreased neutrophil counts } \\
\text { in BALF in berberine- } \\
\text { treated animals }\end{array}$ & $\begin{array}{l}\text { Shin et al. } \\
(2017), \mathrm{Xu} \text { et al. } \\
(2015)^{13,88}\end{array}$ \\
\hline & $\begin{array}{l}\text { P38/MAPK } \\
\text { activity }\end{array}$ & 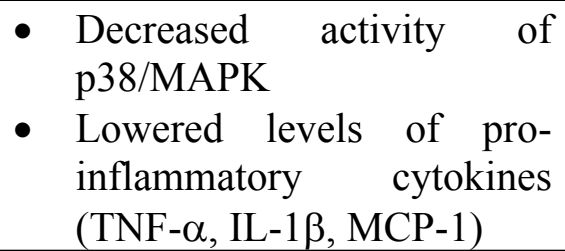 & $\mathrm{Xu}_{88}$ et al. (2015) \\
\hline & iNOS & 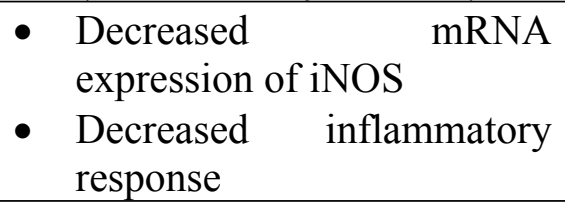 & $\begin{array}{l}\text { Li.C-L et al. } \\
(2019) 87\end{array}$ \\
\hline
\end{tabular}




\begin{tabular}{|c|c|c|c|}
\hline \multirow[t]{4}{*}{ Asthma } & $\begin{array}{l}\text { Thymic Stromal } \\
\text { Lymphopoietin } \\
\text { (TSLP) }\end{array}$ & $\begin{array}{l}\text { - Decreased the production of } \\
\text { TSLP in HMC-1 cells and } \\
\text { primary mast cells in } \\
\text { berberine treatment group } \\
\text { - Decreased TSLP mRNA } \\
\text { expression in HMC-1 cells } \\
\text { in berberine treatment group }\end{array}$ & $\begin{array}{l}\text { Moon et al. } \\
(2011)^{36}\end{array}$ \\
\hline & $\begin{array}{l}\text { Caspase-1 } \\
\text { pathway }\end{array}$ & $\begin{array}{l}\text { - Inhibit caspase-1 pathway } \\
\text { activation, leading to low } \\
\text { TSLP production }\end{array}$ & $\begin{array}{l}\text { Moon et al. } \\
(2011)^{36}\end{array}$ \\
\hline & $\begin{array}{l}\text { NF- } \kappa \mathrm{B} \\
\text { signalling } \\
\text { pathway }\end{array}$ & $\begin{array}{l}\text { - Inhibit NF- } \kappa \mathrm{B} \text { signalling } \\
\text { pathway activation, leading } \\
\text { to low TSLP production }\end{array}$ & $\begin{array}{l}\text { Moon et al. } \\
(2011)^{36}\end{array}$ \\
\hline & & 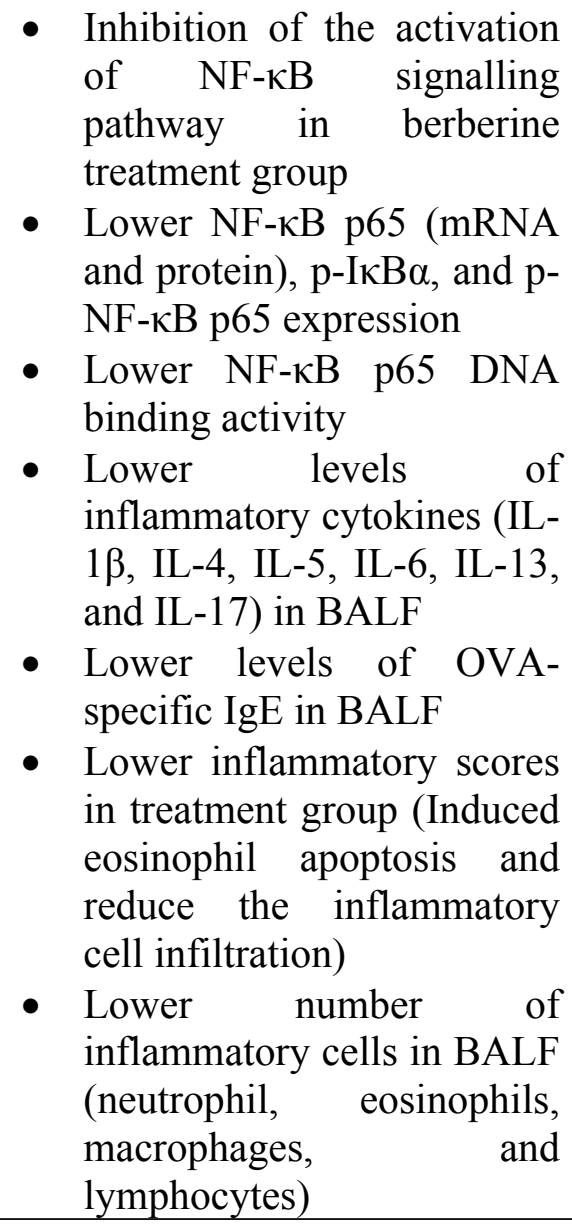 & $\begin{array}{l}\mathrm{Li} \\
41\end{array}$ \\
\hline Pulmonaryfibrosis & $\begin{array}{l}\text { Collagen } \\
\text { accumulation } \\
\text { and deposition }\end{array}$ & $\begin{array}{l}\text { - Lower Ashcroft quantitative } \\
\text { pathological scoring in } \\
\text { berberine treatment group }\end{array}$ & $\begin{array}{l}\text { Chitra et al. } \\
(2013)^{54}\end{array}$ \\
\hline
\end{tabular}




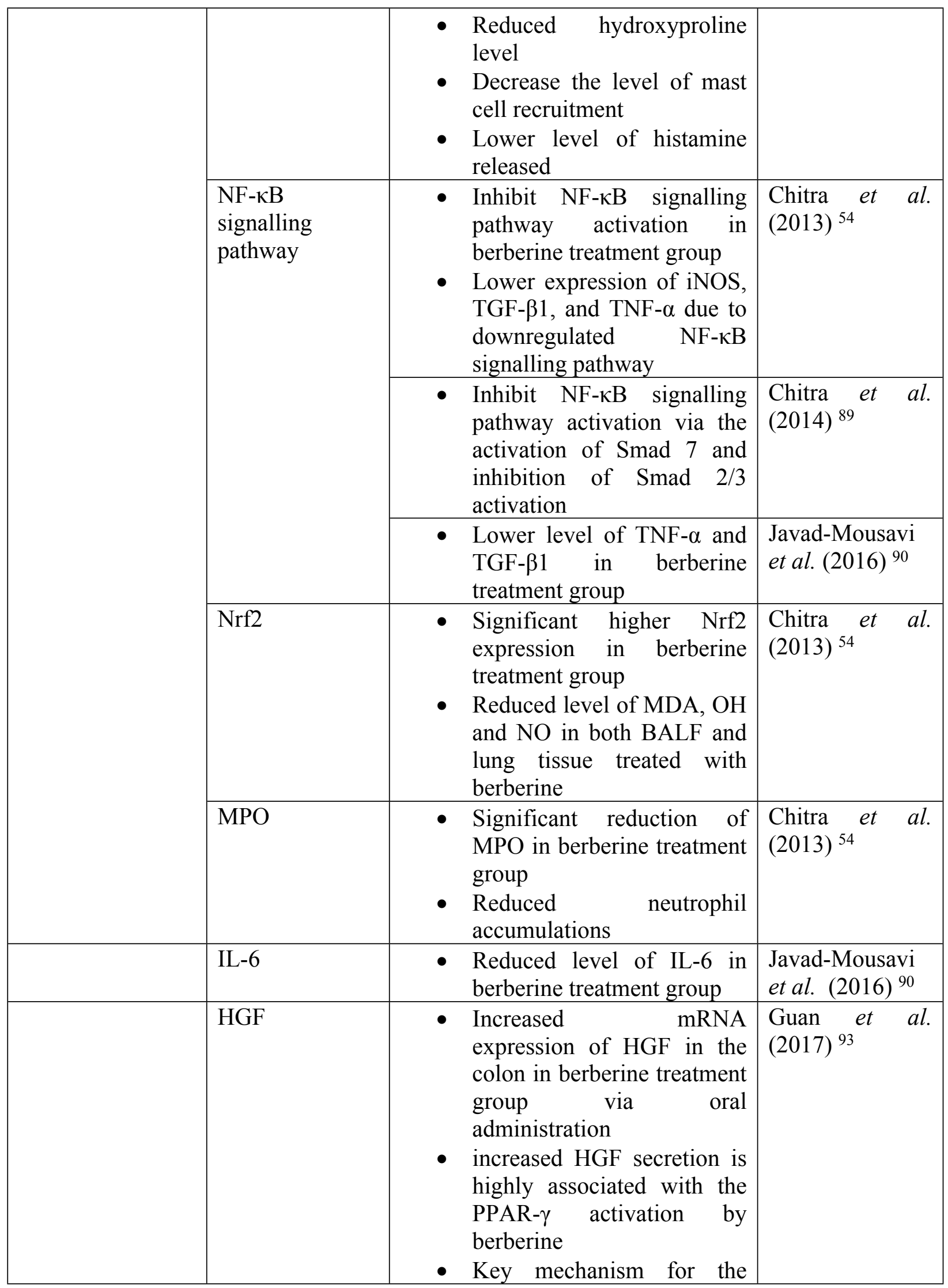




\begin{tabular}{|c|c|c|c|}
\hline & & $\begin{array}{l}\text { anti-fibrotic effect of } \\
\text { berberine }\end{array}$ & \\
\hline & PTEN & $\begin{array}{l}\text { - Increased mRNA } \\
\text { expression of PTEN in the } \\
\text { colon after oral } \\
\text { administration of berberine }\end{array}$ & $\begin{array}{l}\text { Guan et al. } \\
(2017)^{93}\end{array}$ \\
\hline \multirow[t]{5}{*}{ Lung cancer } & $\begin{array}{l}\text { ERK1/2 \& p38 } \\
\text { MAPK pathway }\end{array}$ & 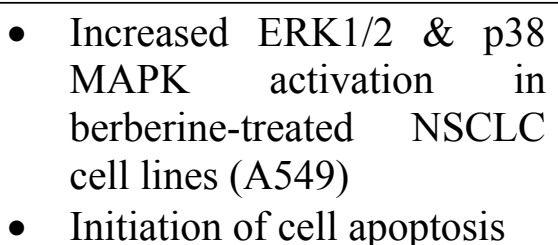 & $\begin{array}{l}\text { Zheng et al. } \\
(2014) 94\end{array}$ \\
\hline & FOXO3a & 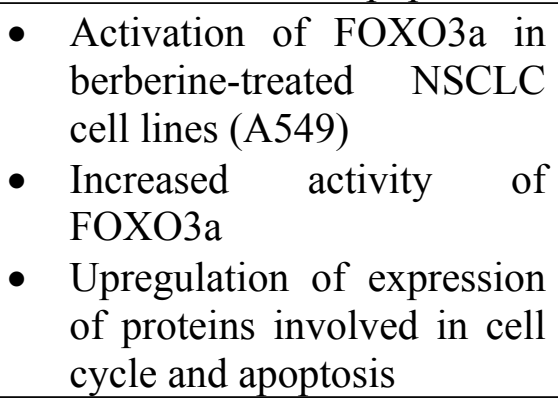 & $\begin{array}{l}\text { Zheng et al. } \\
(2014) 94\end{array}$ \\
\hline & $\begin{array}{l}\text { Pro-apoptotic } \\
\text { proteins (Bax \& } \\
\text { Bak) and anti- } \\
\text { apoptotic } \\
\text { proteins (BcI-2 } \\
\& \text { BcI-x1) }\end{array}$ & $\begin{array}{l}\text { - Upregulation of pro- } \\
\text { apoptotic protein (Bax \& } \\
\text { Bak) and downregulation of } \\
\text { anti-apoptotic (BcI-2 \& } \\
\text { BcI-x1) in berberine-treated } \\
\text { NSCLC cells (A549\& } \\
\text { H1299) } \\
\text { - Initiation cell apoptosis }\end{array}$ & $\begin{array}{l}\text { Santosh et al. } \\
(2009) 97\end{array}$ \\
\hline & Caspase-3 & 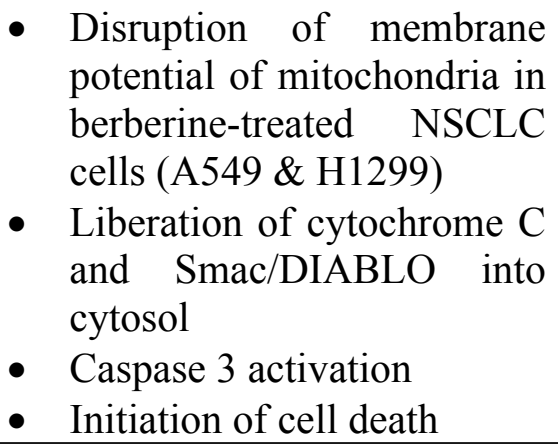 & $\begin{array}{l}\text { Santosh et al. } \\
(2009) 97\end{array}$ \\
\hline & STAT 3 & $\begin{array}{l}\text { - Suppressed activated form } \\
\text { of STAT } 3 \text { in NSCLC cell } \\
\text { lines (NCI-H460 \& NCI- } \\
\text { H1975) } \\
\text { - Inhibition of cell } \\
\text { proliferation } \\
\text { - Initiation of cell apoptosis }\end{array}$ & $\begin{array}{l}\text { Zhu et al. (2015) } \\
98\end{array}$ \\
\hline
\end{tabular}


Table 2: Most common supplements containing berberine that are manufactured in the US

\begin{tabular}{|c|c|c|c|}
\hline No. & Name of the marketed formulation & $\begin{array}{l}\text { Manufactured and } \\
\text { marketed by }\end{array}$ & Active constituent \\
\hline 1. & $\begin{array}{l}\text { Sunergetic Premium Berberine } \\
\text { Supplement }\end{array}$ & Sunergetic, USA & $\begin{array}{l}\text { Each pill contains } \\
\text { berberine } \\
\text { hydrochloride } \\
\text { extract equivalent to } \\
1200 \mathrm{mg} \text { of berberine }\end{array}$ \\
\hline 2. & Thorne Research Berberine & $\begin{array}{l}\text { Thorne Research, } \\
\text { USA }\end{array}$ & $\begin{array}{l}\text { Each pill contains an } \\
\text { equivalent amount } \\
\text { of } 1000 \mathrm{mg} \text { of } \\
\text { Berberine } \\
\text { hydrochloride }\end{array}$ \\
\hline 3. & Dr. Whitaker's Berberine & $\begin{array}{l}\text { Whitaker Wellness } \\
\text { Institute, USA }\end{array}$ & $\begin{array}{l}\text { Each capsule } \\
\text { contains an } \\
\text { equivalent amount } \\
\text { of } 500 \mathrm{mg} \text { of Pure } \\
\text { Berberine HCL }\end{array}$ \\
\hline 4. & We Like Vitamins Berberine & $\begin{array}{l}\text { We Like Vitamins, } \\
\text { USA }\end{array}$ & $\begin{array}{l}\text { Each pill contains an } \\
\text { equivalent amount } \\
\text { of } 900 \mathrm{mg} \text { of } \\
\text { Berberine HCL }\end{array}$ \\
\hline 5. & Swanson Berberine & $\begin{array}{l}\text { Swanson Vitamins, } \\
\text { USA }\end{array}$ & $\begin{array}{l}\text { Each pill contains an } \\
\text { equivalent amount } \\
\text { of } 400 \mathrm{mg} \text { of } \\
\text { Berberine HCL }\end{array}$ \\
\hline
\end{tabular}




\section{Declaration of interests}

૫ The authors declare that they have no known competing financial interests or personal relationships that could have appeared to influence the work reported in this paper.

$\square$ The authors declare the following financial interests/personal relationships which may be considered as potential competing interests:

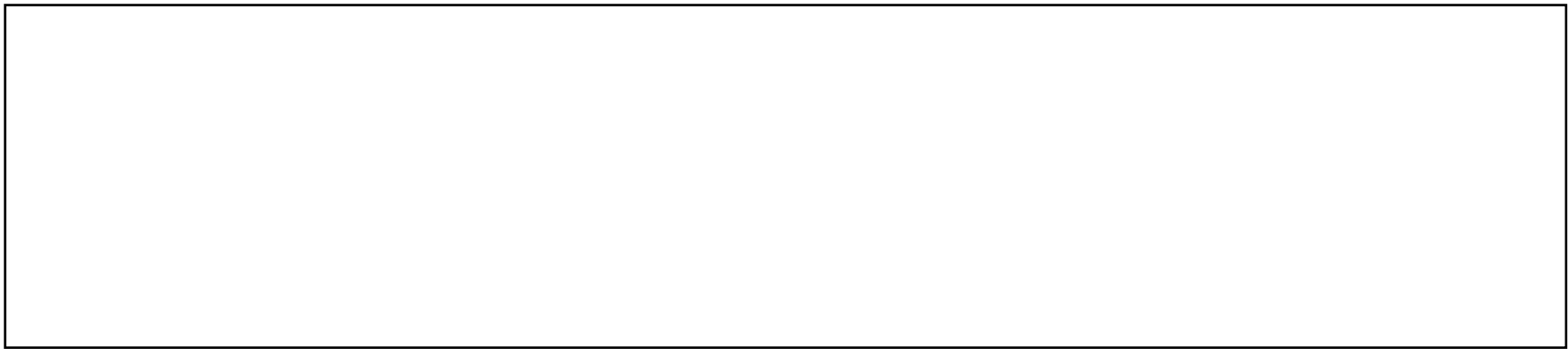

